Discussion Paper No. 11-077

\title{
The Rat Race of Capital Structure Research for REITs and REOCs:
} Two Spotlights on Leverage

Ralf Hohenstatt and Bertram Steininger

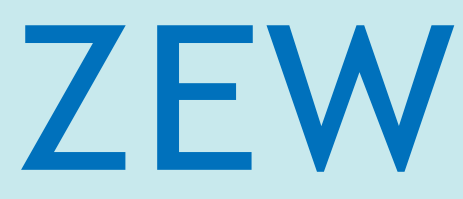

Zentrum für Europäische Wirtschaftsforschung $\mathrm{GmbH}$ Centre for European Economic Research 
Discussion Paper No. 11-077

\title{
The Rat Race of Capital Structure Research for REITs and REOCs: Two Spotlights on Leverage
}

\author{
Ralf Hohenstatt and Bertram Steininger
}

Download this ZEW Discussion Paper from our ftp server:

http://ftp.zew.de/pub/zew-docs/dp/dp11077.pdf

Die Discussion Papers dienen einer möglichst schnellen Verbreitung von neueren Forschungsarbeiten des ZEW. Die Beiträge liegen in alleiniger Verantwortung der Autoren und stellen nicht notwendigerweise die Meinung des ZEW dar.

Discussion Papers are intended to make results of ZEW research promptly available to other economists in order to encourage discussion and suggestions for revisions. The authors are solely responsible for the contents which do not necessarily represent the opinion of the ZEW. 


\section{Non-Technical Summary}

Since the seminal work of Franco Modigliani and Merton Miller in 1958, no generally accepted capital structure theory has emerged. Consequently this paper does not aim to validate any of the capital structure theories. In fact, in our paper we focus on 'financial flexibility' as an important determining factor for the capital structure of firms according to surveys among CFOs (see e.g. Sufi (2009) and Lins, Servaes, and Tufano (2010)). Gamba and Triantis (2008) directly address this concept and provide the following definition: "Financial flexibility represents the ability of a firm to access and restructure its financing at a low cost. Financially flexible firms are able to avoid financial distress in the face of negative shocks, and to readily fund investment when profitable opportunities arise."

We hypothesize that financial flexibility - as the interactions of leverage, cash \& cash equivalents and lines of credit - is a broader, but more consistent, concept in explaining the dynamics of financing activities than traditional capital structure theory. In our study, leverage - the pivotal point of every capital structure study - is investigated by two spotlights. Spotlight A is defined as financial flexibility, in the sense of anticipating liquidity management. In this context, we analyze the deviation of the most important balance sheet items induced by changes of leverage, cash \& cash equivalents and lines of credit. This approach, albeit new in its broad extent, is the classical model organization of capital structure studies. The innovative spotlight B distinguishes between real stochastic and mainly mechanical relationships of the ratio 'leverage' and its fractionalized debt and equity component. This approach takes into account that the leverage ratio of an average firm reverts to mean mechanically. Without knowledge of this characteristic, the economic interpretation of the results could be misleading (Chen and Zhao (2007)).

Our results are based on observing US Real Estate Investment Trusts (REITs) and Real Estate Operating Companies (REOCs) from 1995 to 2010. By focusing on real estate data, we avoid a dilution of different industry sector effects. The results of perspective A emphasize the substitutive relationship between leverage and credit lines, backed by the existing literature. This clarifies the importance of credit lines for firms' liquidity management. The positive influence of leverage on cash \& cash equivalents is new evidence and contrary to previous research. This effect - which appears especially in downturns - can be explained by the firms' strategy to accumulate cash to fund investment when profitable opportunities arise. The results of perspective B confirm our hypothesized effect that leverage as a ratio would neglect the specific influence on its components and cause misleading interpretation of the effects. At this point, we would like to point out the influence of operating cash flow. In economic upturns, a cash flow increase impacts more investments, financed by equity, but leverage remains unchanged. In downturns, investment expenses are funded by debt corresponding with a leverage increase. Besides these highlighted results, our paper presents the influence of eight traditional and new capital structure variables in 22 different subsamples for perspective A as well as for B. 


\section{Das Wichtigste in Kürze}

Seit der grundlegenden Arbeit zum Gebiet der Kapitalstruktur von Franco Modigliani und Merton Miller aus dem Jahr 1958 konnte sich bis dato keine Kapitalstrukturtheorie als allgemeingültig durchsetzen. Daher beabsichtigt dieser Artikel auch nicht eine der Theorien zu bewerten, sondern konzentriert sich auf ein relativ neues Konzept als einen der wichtigsten Treiber für das Kalkül von Finanzierungsentscheidungen, die 'finanzielle Flexibilität'. Deren Bedeutung wurde bereits in mehreren wissenschaftlichen Umfragen unter Finanzvorständen hervorgehoben (siehe z.B. Sufi (2009) und Lins et al. (2010)). Gamba und Triantis (2008), die ebenfalls in ihrem wissenschaftlichen Artikel das Konzept aufgreifen, geben dabei folgende Definition: "Finanzielle Flexibilität repräsentiert die Fähigkeit einer Unternehmung, auf Finanzierungsaktivitäten zu geringen Kosten zuzugreifen und diese neu zu strukturieren. Finanziell flexible Firmen sind dabei in der Lage, finanzielle Engpässe in Zeiten negativer Marktbedingungen zu vermeiden und Investitionen zu tätigen, sobald sich gewinnbringende Möglichkeiten ergeben."

Wir stellen die Hypothese auf, dass die 'finanzielle Flexibilität', also das Zusammenspiel von Verschuldungsgrad, kurzfristig verfügbarem Kapital und zugesagten Kreditlinien, ein breiteres aber dennoch einheitlicheres Konzept im Vergleich zu traditionellen Kapitalstrukturtheorien darstellt, um die Wechselbeziehungen von Finanzierungsaktivitäten und Bilanzposten zu erklären. In unserer Untersuchung wird der Verschuldungsgrad - das Hauptaugenmerk jeder Kapitalstrukturstudie - aus zwei Perspektiven beleuchtet. Perspektive A erfasst die finanzielle Flexibilität im Sinne des Liquiditätsmanagements. Wir analysieren in diesem Zusammenhang die Abweichungen der wichtigsten Bilanzposten, die sich durch Änderungen bei Verschuldungsgrad, kurzfristig verfügbarem Kapital und zugesagten Kreditlinien, ergeben. Dieser Ansatz, auch wenn in seinem Umfang neu, entspricht der klassischen Herangehensweise bei Untersuchungen von Kapitalstrukturfragen. Die innovative Perspektive B unterscheidet zwischen der mechanischen Beziehung des Quotienten 'Verschuldungsgrad' und den Änderungen seiner einzelnen Komponenten 'Eigen- und Fremdkapital'. Hierbei wird der Tatsache Rechnung getragen, dass der Verschuldungsgrad aufgrund seiner Konstruktion rein mechanisch zum Mittelwert zurückkehrt und eine Vernachlässigung dieser Eigenschaft zu einer Fehlinterpretation der Ergebnisse führen würde (Chen und Zhao, 2007).

Unsere Ergebnisse basieren auf den Daten von US-amerikanischen Real Estate Investment Trusts (REITs) und Real Estate Operating Companies (REOCs) im zur Verfügung stehenden Zeitraum von 1995 bis 2010. Die Beschränkung auf diesen reinen Immobiliendatensatz ermöglicht es, sich auf branchentypische Einflüsse zu fokusieren. Die Ergebnisse für Perspektive A verdeutlichen nochmals den aus der aktuellen Literatur bekannten substitutiven Effekt zwischen Verschuldungsgrad und Kreditlinien. Dieses Resultat unterstreicht die ökonomische Bedeutung der Kreditlinie als Liquiditätsmanagementinstrument für die Unternehmen. Bemerkenswert und neu ist das Ergebnis, dass Erhöhungen des Verschuldungsgrads auch zur marginalen Erhöhung des kurzfristig verfügbaren Kapitals führen. Ein Effekt, der vor allem vor der Finanzkrise zu beobachten war und als strategische Akkumulation von Kapital für zukünftige Projekte zu verstehen ist. Die Ergebnisse für Perspektive B bestätigen die vermutete Annahme, dass der Verschuldungsgrad Informationen verschluckt und eine reine Betrachtung der Größe 'Verschuldungsgrad' zu Fehlinterpretationen führen würde. Hervorzuheben ist hierbei der Einfluss des operativen 
Cashflows auf die Bilanzstruktur. In Zeiten wirtschaftlichen Aufschwungs führt eine Erhöhung des Cashflows zu Investitionsausgaben, die durch Eigenkapital finanziert werden, und zu keinem signifikanten Einfluss auf den Verschuldungsgrad. Dahingegen werden im Abschwung Investitionsausgaben v. a. durch eine Fremdkapitalerhöhung finanziert, die den Verschuldungsgrad steigen lassen. Neben diesen Ergebnissen liefert die Studie sowohl für Perspektive A als auch B den Einfluss von acht verschiedenen traditionellen und neueren Kapitalstruktureinflussgrößen in 22 verschiedenen Subsamples. 


\title{
The Rat Race of Capital Structure Research for REITs and REOCs: Two Spotlights on Leverage
}

\author{
Ralf Hohenstatt* $\quad$ Bertram Steininger ${ }^{\dagger}$
}

This version: December 2011

\begin{abstract}
This paper presents a dynamic multi-equation model based on a balance sheet identity, where technical aspects of capital structure are highlighted through separately observing debt and equity and their relationship to investment. Additionally, leverage dynamics are interpreted in their role for liquidity management. Interactions of leverage with lines of credit (LOC) and cash are considered in the light of financial flexibility. The major findings obtained by observing US REITs and REOCs from 1995 to 2010 are as follows. In accordance with the existing literature, cash and LOC reveal a substitute relationship. However, the calculus of financial flexibility and our findings suggest that leverage positively drives cash, which is consistent with Gamba and Triantis (2008), and also with the accepted perspective of debt minus cash being net debt (Spotlight A). Consequently, the very robust results indicate that leverage eliminates a significant amount of information. Further mechanical relationships, especially for market leverage, are suggested (Spotlight B).
\end{abstract}

JEL Classification Codes: G32, G33, G35

Key Words: Capital structure, Real Estate Investment Trust (REIT), Real Estate Operating Company (REOC), financial flexibility, cash flow sensitivities, leverage ratio, lines of credit, cash \& cash equivalents

${ }^{*}$ University of Regensburg, 93040 Regensburg, Germany, Phone: +49-941-943-5077, Fax: +49-941943-5072, Email: ralf.hohenstatt@irebs.de.

${ }^{\dagger}$ Centre for European Economic Research (ZEW), L7, 1, 68161 Mannheim, Germany, Phone: +49-621-1235-146, Fax: +49-621-1235-223, Email: steininger@zew.de, (corresponding author).

We would like to thank the participants of the ERES Conference 2011 in Eindhoven and the ARES Conference 2011 in Seattle for their useful and constructive comments. Opinions and errors are solely the responsibility of the authors and not of the institutions with whom the authors are affiliated. 


\section{Introduction}

The persistently large number of capital structure studies since the seminal work of Modigliani and Miller (1958) does not yield consistent evidence for one specific capital structure theory. This study does not aim to validate any of these theories, but follows Graham and Harvey (2001), who state that "financial flexibility is the single most important determinant of capital structure according to CFOs". Investigating firm cash holdings, Opler, Pinkowitz, Stulz, and Williamson (1999) argues: "Firms want to avoid situations where the agency costs of debt are so high that they cannot raise funds to finance their activities and invest in valuable projects. Obviously, one way to do so is to choose a low level of leverage." A more recent example of this stream of research is the proposal of DeAngelo and DeAngelo (2007), aimed at filling the gap in capital structure theory and the associated empirical findings. They state: "Financial Flexibility is the critical missing link for an empirically viable [capital structure] theory." Gamba and Triantis (2008) directly address this concept and provide the following definition: "Financial flexibility represents the ability of a firm to access and restructure its financing at a low cost. Financially flexible firms are able to avoid financial distress in the face of negative shocks, and to readily fund investment when profitable opportunities arise."

In the present study, approximation leverage (LEV) is investigated by two spotlights. Financial flexibility, in the sense of anticipating liquidity management, is addressed by Spotlight A. Interactions of LEV with cash \& cash equivalents (CCE) and lines of credit (LOC) form the focus. The more technical one (Spotlight B) is motivated by the arguments of Chen and Zhao (2007) and Gatchev, Pulvino, and Tarhan (2010). Spotlight B ensures robust results, distinguishing between real stochastic and mainly mechanical relationships.

The recent late-2000s financial crisis in particular, provides the motivation for investigating Spotlight A. There is consensus in the existing literature on a substitute relationship between $\mathrm{CCE}$ and LOC. This is due to the fact that LOC hedge against 
underinvestment, and CCE against cash flow (CF) shortfalls (Lins, Servaes, and Tufano (2010)). However, what was evident immediately after the peak of the crisis is that firms draw their available LOC, fearing that they will be canceled due to covenant breaks (Campello, Graham, and Harvey (2010). Sufi (2009) also supports the view that CCE and LOC are only conditional substitutes. Therefore, this study aims to fill the gap in the literature, by including LEV in the interactions of sources of liquidity management. Furthermore, another issue of the late-2000s financial crisis is the perceived increased relevance of the real estate industry. Many studies argue that there is homogeneity in the REIT industry due to legislation, e.g. aspects such as the role of taxes or retained cash flows are of lower relevance. Hence, more consistent findings are expected when concentrating on REITs. Another interesting circumstance within this industry is the underutilization of CCE, as opposed to a similar level of importance of LOC, compared to companies outside the real estate industry. This may be due to the fact that the high dividend payout restriction prevents REITs from accumulating cash. Yet, recent research by Harrison, Panasian, and Seiler (2011) reports that REITs voluntarily choose to pay 'excess dividends' - up to $38 \%$ of their total assets.

This paper is organized traditionally. Section 2 provides an overview of the related literature. In section 3, the data are described. Section 4 introduces our model. In section 5 , we present the results and section 6 concludes.

\section{Literature Review}

\subsection{General Motivation}

At first, both the general finance literature, as well as real estate studies, seem to reach no empirically robust consensus on classical capital structure theories. One could cautiously claim that recent research in this field agrees on a mixture of trade-off and market-timing theory as valid. This is justified mainly by market timing allowing equity issuances to 
be preferable in some states of the economy 11 Furthermore, LEV often reveals a meanreversion characteristic; hence, target-leverage is interpreted as a validation of the tradeoff theory (Flannery and Rangan $(2006))$.

Hence, the second argument is motivated by Chen and Zhao (2007), who demonstrate, using the sample of Flannery and Rangan (2006), how their findings can be justified by a purely mechanical characteristic. This is due to the fact that leverage is 'just' a ratio and has insufficient implications for capital structure dynamics, thus making it an inadequate tool for distinguishing between different financing policies.

The third argument is based on the relevance of taxes to financing decisions, if one argues in favor of the trade-off theory. Blouin, Core, and Guay (2010) investigate the widespread belief in the underutilization of debt. This is supported indirectly by DeAngelo and DeAngelo (2007). They do not exclude a tax-shield, but emphasize that preserving debt capacity, in order to forego investment distortions in the near future, outweighs the "few cents on the dollar" benefit of debt. Finally, the present study observes mainly REITs, which are pass-through entities with respect to the main business activities. Hence, a tax-shield is assumed to be of no relevance for this paper.

DeAngelo and DeAngelo (2007) recognize the dilemma of capital structure research and formulate a draft aimed at filling the gap between the traditional theories and empirical findings. They argue that it is the 'equity as the last resort' attribute of the pecking-order theory, and the 'non-occurrence of levering up after stock price increases' of market-timing, and the 'high dividend-low leverage' characteristic of profitable firms of trade-off theory which necessitate innovations in this field of research. Their alternative approach to explaining capital structure is based on interpreting management actions in the light of financial flexibility, e.g. preserving debt capacity for facilitating potential future financial needs.

\footnotetext{
${ }^{1}$ For this reason, pecking-order is often rejected, but seems to be valid for large firms with low marketto-book-ratio but high cash-flows (Leary and Roberts $(2010))$.
} 
Kelly (2009) confirm a substitutive relationship between CCE and LOC. Moreover, the authors state that REIT managers choose not to accumulate cash, preferring to finance externally, gaining from reduced agency conflicts of monitoring and reduced costs of financing.

While empirical evidence suggests a negative relationship between LEV and CCE (Opler, Pinkowitz, Stulz, and Williamson (1999); Ozkan and Ozkan (2004); Hardin, Highfield, Hill, and Kelly (2009)), our perspective suggests a positive, but non-linear relationship. This becomes clear when considering the insurance aspects of both instruments: low leverage preserves debt capacity, i.e. the ability to borrow in the future, high cash reserves hedge against the risk of underinvestment and cash flow shortfalls, but mainly against the latter. This view is supported by Lins, Servaes, and Tufano (2010), who find no significant (contemporaneous) relationship, but refer to argument which we have just stated. Denis and Sibilkov (2010) also favor the hedging argument of CCE for underinvestment, but predict a negative correlation of LEV and CCE. Gamba and Triantis (2008) investigate a firm's financial flexibility, driven by levels of borrowing and lending. By controlling cash and debt, the resulting positive net debt implicates a higher firm value, although with a decreasing marginal effect with respect to the mixture of cash and debt.4 Acharya, Almeida, and Campello (2007) also argue that CCE constitutes negative debt. Their implications are dependent on varying degrees of hedging needs, namely a lower risk of underinvestment implicating that firms pay down their outstanding debt.

Moreover, a negative relationship between LEV and LOC seems to be empirically robust, as well as consistent with the calculus of financial flexibility. Riddiough and Wu (2009) declare that REITs increased dividend payout in the 1990 to 2003 period, leaving these specific companies with lower cash reserves than non-REITs, whereas the use of LOC is comparable. Therefore, interpreting a high LEV as the inability to borrow in the ${ }_{4}^{4}$ Hill, Kelly, and Hardin $(2010)$ report a $\$ 1.34$ increase ( $\$ 0.30$ decrease) of firm value due to a $\$ 1$ increase of CCE (one standard deviation increase of unused LOC) based on empirical investigation of REITs. 
future (e.g. Gamba and Triantes 2008) - and hence classified as the reciprocal of debt capacity - LEV and LOC yield reverse dynamics. Second, LEV accounts for drawing LOC and the change of other external sources of finance. Third, since the dynamics between LEV and CCE, as well as LOC, have not been comprehensively empirically investigated, the stochastic properties of the variables of interest would allow at least the following prediction. Assuming that CCE and LOC are not independent of each other, namely negative, a reverse relationship of LEV applies to each of them. Assuming positive CCELEV dynamics, the hypothesized sign of LEV and LOC follows technically.

Summarizing the arguments of Spotlight A, the liquidity sources have different tasks, but are dependent on firm characteristics, as well as the state of the economy. Moreover, a preference for one or the other may depend on the original level.

\subsection{Spotlight B: Leverage is 'just' a Ratio}

The second spotlight on leverage takes properties of this ratio into account. If equity and debt increase by the same percentage, a leverage ratio will simply cancel out these dynamics, but total (i.e. non-current) assets increase. The relative position of debt still plays a significant role in terms of anticipative liquidity policy, but in order to differentiate between financial actions, debt and equity must be treated separately.

Today's decisions are determined jointly, they are dependent on what happened in the past and also influence the (unknown) future. Therefore, the first imperative, when dealing with financial flexibility is dynamic modeling. Gatchev, Pulvino, and Tarhan (2010) distinguish between debt and equity, and do so between all the main aggregates from the cash-flow statement - one example of a more cash-flow-focused mentality since the late-2000s financial crisis. The authors detect a much lower sensitivity of investment to shocks to cash flows, concluding that financing sensitivity with respect to cash flows is much more relevant than investment responses. Gatchev, Pulvino, and Tarhan (2010) define an identity where one dollar cash in-flow corresponds exactly to one dollar cash 
outflow. Chen and Zhao (2007) also worked with an accounting identity in which assets are defined by last year's assets plus the change in debt, equity and retained earnings. The authors suggest that firms levered below the median increase leverage by increasing debt, but highly levered firms increase equity while decreasing debt. Almeida and Campello (2007) also investigate financing-investment sensitivities with respect to the state of the market and firm characteristics. They agree that cash-flow shocks affect primarily constrained firms. However, the portion of tangible assets in particular, determines the procyclical aspect of debt capacity with respect to the business cycle.

In summary, the importance of distinguishing between the numerator and denominator of LEV is the focus of the second spotlight on LEV. In addition to research surrounding LEV, CCE and LOC, the relevance of real assets (investment) and cash flow is determined. DeAngelo and DeAngelo (2007) suggest "new testable hypothesis [...] for future research [...] [is that] firms' long-run leverage targets are inversely related in cross-section and time-series to the (investment distortion-reducing) value of financial flexibility."

\subsection{Research Goal from a Bird's Eye}

In a perfect world, there is no need to hoard cash or hedge in any other way, because firms have access to the capital market at any time without transactions costs, when investment opportunities arrive. Opler, Pinkowitz, Stulz, and Williamson (1999) define a firm as being short of liquid assets, if it has to sell assets or cut capital expenditures or dividends. By contrast, this paper considers how, dependent on the state of the economy and firm characteristics, investment funding is influenced by the drivers of financial flexibility, namely debt capacity (reciprocal LEV), CCE and LOC. However, we adjust the concept of assuming an optimum amount of 'financial flexibility'. The marginal costs of being short of money in periods when a firm would actually need funding are a decreasing function with respect to instruments of financial flexibility. On the other hand, foregoing borrowing power in terms of LEV (on balance, but not directly measurable in terms of being financially constrained), the opportunity costs of CCE (on balance and 
fully measurable) and fees for the availability of LOC (off balance and partly measurable in terms of efficiency) act in a contrary manner, so as to antagonize these marginal costs. Therefore, there has to be an optimum where the marginal costs of underinvestment and financial distress coincide with the costs associated with being financially flexible. Despite the fact that CCE plays a minor role for real estate companies, this is an unconditional source for hedging underinvestment, if outside investors are unwilling to provide funds. Yet, cash hedges particularly effectively in economic downturns, since a low-leverage firm would still be dependent on external capital. LOC agreements could be canceled in the event of covenant breaks. However, of the three sources, CCE is associated most strongly with costs of asymmetric information, because outsiders doubt the appropriate use by managers, while debt has the advantage of monitoring (Hardin, Highfield, Hill, and Kelly $(2009)) \cdot 5$

Figure 1: Concept of Financial Flexibility

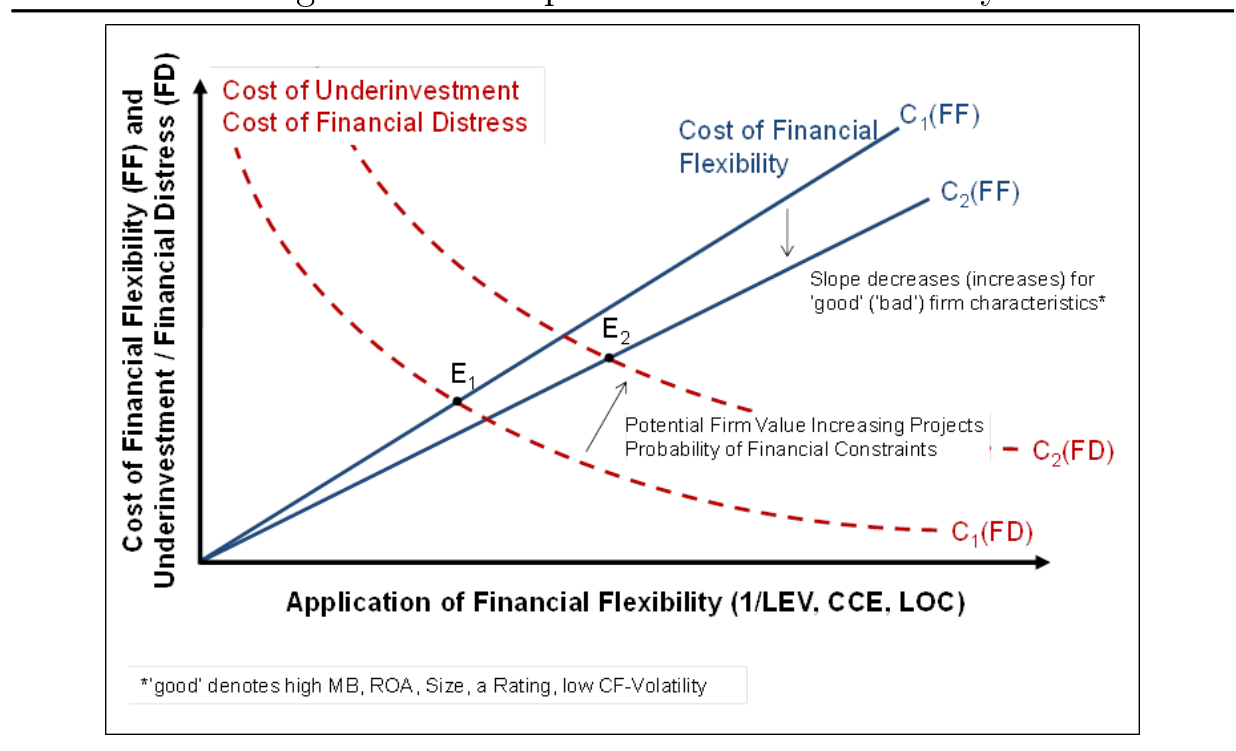

Note: This figure depicts the equilibrium between the costs of financial flexibility and (in-)direct costs associated with underinvestment and financial distress.

From this perspective, the objective function describes the ability to secure sufficient financial resources and to raise sufficient financial resources to implement profitable investments with respect to uncertainty and the efficiency constraint in terms of the direct ${ }^{5}$ For the relevance of information asymmetry for a firm's choice between CCE and LOC, see also An, Hardin, and Wu (2010). 
and indirect costs of financial flexibility. We hypothesize that financial flexibility is a broader, but more consistent concept in explaining the dynamics of financing activities, compared to traditional capital structure theory.

\section{Data}

The SEC statements compiled by SNL Financial are the basis of our panel data set. The initial sample contains 316 operating and acquired or defunct US Equity REITs and REOCs traded on the NYSE, NYSE Amex Equities and NASDAQ from 1996 to 2010, with $56 \%$ non-missing values. Company foundations and liquidations are responsible for $79 \%$ of the missing values, whereas $21 \%$ are due to unreported data. The broad announcements of cash flow statements in SNL from 1996 onwards, as well as the dynamic modeling, including lagged differences, restrict the sample to the 1998-2010 period and eliminate 36 firms with less than three consecutive years..$^{6}$

Table (1) provides definitions and computations of the variables and approximations used in this study. All financial variables are truncated at the 5 th and $95^{\text {th }}$ percentile. LEV (LOC) is cut at the $95^{\text {th }}$ percentile only, because $6 \%(9 \%)$ of the observations are zero. The truncation is to a lesser extent intended to reduce the influence of outliers, rather than to focus the study on firms with typical financial characteristics. Subsequently, the end-of-year financial data are deflated by the US Producer Price Index of the US Bureau of Labor Statistics. Therefore, the final sample includes 140 Equity REITs and REOCs corresponding to 558 firm-year observations.

Research on cash balances suggests the need to scale variables by non-cash assets, in order to forego mechanical relationships (see Sufi (2009)), analogous to the arguments associated with Spotlight B. However, since debt scaled by assets (leverage) would decrease after CCE scaled by non-cash assets has increased for mechanical reasons, we scale

\footnotetext{
${ }^{6} \mathrm{~A}$ further reason for starting in 1996 is the beginning of a consolidation phase, after a boom of the REIT sector in the 1990s.
} 
Table 1: Variable Description

\begin{tabular}{|c|c|c|}
\hline Variable & Description & Definition \\
\hline \multicolumn{3}{|c|}{ Balance Sheet Aggregates } \\
\hline STD & Short-term debt & Debt payable within a business year \\
\hline LTD & Long-term debt & Debt payable after a business year \\
\hline EQU & Common equity & (shareholder equity) - (preferred equity) \\
\hline DPROP & Depreciable property & PPE + accumulated depreciation \\
\hline NFI & Net of financing and investment cash flow & $\Delta \mathrm{CCE}-\mathrm{CF}_{-} \mathrm{Op}$ \\
\hline \multicolumn{3}{|c|}{ Instruments of Liquidity Management } \\
\hline $\mathrm{CCE}$ & Cash \& cash equivalents & Cash or assets easily convertible into cash \\
\hline LEV & Market leverage & (total debt) / (market value of assets) \\
\hline LOC & Lines of credit & $\begin{array}{l}\text { Aggregate lines of credit and other } \\
\text { revolving credit agreements available }\end{array}$ \\
\hline $\mathrm{CF}_{-} \mathrm{Op}$ & Operating $\mathrm{CF}$ & Net cash provided by operating activities \\
\hline \multicolumn{3}{|c|}{ Control Variables } \\
\hline S\&P500 & Standard \& Poor's 500 Index & $\ln \left(\mathrm{S} \& \mathrm{P} 500_{t} / \mathrm{S} \& \mathrm{P} 500_{t-1}\right)$ \\
\hline MB & Growth opportunities & (market equity) / (book equity) \\
\hline ROA & Profitability & Return on assets \\
\hline Size & Size of a firm & $\ln$ (total assets) \\
\hline \multicolumn{3}{|l|}{ Dummies } \\
\hline Rating & Access to public debt & 1 if firm has investment-grade rating \\
\hline Op Risk & Operating risk & 1 if firm has $C F$ volatility above the median \\
\hline Inv_Shock & Investment shock & 1 if $\%$-change is above the $55^{\text {th }}$ percentile $\ldots$ \\
\hline FFO__Shock & Shock on sustainable CF & $\begin{array}{l}1 \text { if } \% \text {-change is below the } 45^{\text {th }} \text { percentile } \ldots \\
\ldots \text { and } 0 \text { otherwise }\end{array}$ \\
\hline
\end{tabular}

Note: The table describes the variables used in the dynamic model for the two spotlights on leverage. Mean and standard deviations of the dependent variables in the multi-equation framework are reported in the respective estimation reports for the full sample, as well as for each subsample.

variables with the beginning of the period value of total assets, rather than divide the variables by non-cash-and-debt assets.

\section{1 (Balance Sheet) Items Defining the Identity}

The variables STD for short-term debt, and LTD for long-term debt, describe the liabilities of the company to a third party, whereas EQU for common equity, describes the claims of the shareholders. DPROP for depreciable property is calculated as the sum of property, plant and equipment (PPE) and accumulated depreciation. The differences between DPROP over time characterize the net expenditures of the company in PPE. In line with Harrison, Panasian, and Seiler (2011), real estate investment, as the source of collateral and asset tangibility, should increase the debt capacity of a firm. However, from our point of view, net property (real estate) investment foregoes the link of internal financing through depreciation $\sqrt{7}$ Hence, approximating the change in fixed assets by $\sqrt[7]{\text { Riddiough and } \mathrm{Wu}(2009)}$ report that the $90 \%$ payout restriction transfers to $55 \%-70 \%$ pre-dividend payout, whereas An et al. (2010) relate this to $85 \%$ of FFO. Both figures highlight the relevance of 
DPROP does not dilute the actual stock of real estate. Apart from minor aggregates, the sum of operating, investment and financing cash flow is the change in CCE and completes the identity, which is introduced in detail in the next section.

\subsection{Instruments of Liquidity Management}

The following sources are defined as the instruments of liquidity management. Cash \& cash equivalents (CCE) describe the potential of the internal finance source for future projects and increase the firm's financial flexibility. By contrast, market leverage (LEV) is the ratio of total debt to the market value of assets and lowers a firm's debt capacity. While market LEV is used throughout the analysis, the results are also compared to book LEV, which is total debt to year-beginning total assets. The available lines of credit (LOC) are a revolving debt source extended by a bank. On the one hand, they offer future financial flexibility for the firm, but on the other hand, they are subject to fees for the unused lines.

\subsection{Traditional Capital Structure Determinants}

The following determinants are typical control variables used in capital structure studies. The general (stock) market cycles influence the development of real estate firms with respect to systematic risks and opportunities. This impact is incurred through the continuous returns of the S\&P500. The market-to-book ratio (MB), calculated by market equity divided by book equity, characterizes the idiosyncratic growth opportunity 8 The profitability of a firm - measured by return on assets (ROA) - may also influence the capital structure, as it is easier to issue debt and equity for more profitable firms. The size of a firm is captured by the natural logarithm of its total assets, assuming decreasing marginal economies of scale. With respect to balance sheet aggregates, a mechanical size effect on DPROP, STD, LTD and EQU is mitigated, due to scaling by total assets.

\footnotetext{
depreciation for internal funding

${ }^{8}$ Traditionally, MB is approximated by the deviation of market and book value of assets, rather than equity. In order to reduce the mechanical relationship to market leverage, the latter possibility is chosen.
} 


\subsection{Additional Dummies Approximating Firm Characteristics}

The dummy Rating has a value of one, if the firm has at least an investment grade longterm issuer rating from $\mathrm{S} \& \mathrm{P}$, Moody's or Fitch. It approximates access to the public debt market, due to relatively lower transaction costs and levels of asymmetric information. The dummy Op_Risk equals one, if the volatility of operating CF exceeds the conditional median of the twelve different property segments. It approximates the operational risk confronting a real estate company.

The two remaining dummies are unique to our research. As derived in the literature section, it is of interest to determine whether a firm faces strong investment opportunities or substantial CF shortfalls. Therefore, the Inv_Shock variable summarizes all observations with a percentage change of the market-to-book ratio above the $55^{\text {th }}$ percentile, conditional on the property segments. The computation for the FFO_Shock is similar. This determinant indicates observations with low percentage changes in funds from operations (FFO), if the changes are below the conditional $45^{\text {th }}$ percentile. FFO is typically calculated by adding real estate depreciation to the GAAP net income, excluding gains or losses from sales of properties or debt restructuring, and is interpreted as the sustainable cash flow. Observations with low (more negative) percentage changes in their FFOs are assumed to trigger higher leverage and lower equity.

\subsection{Dealing with Cross-Industry Variation}

It is common in real estate finance to allow for varying intercepts for different property segments. However, Ertugrul and Giambona (2011) show that the relative standing of a firm within its property focus segment ("micro industry") is essential for determining leverage. The rationale behind this approach is simply that it is not appropriate to compare profitability, leverage, or, as in this study, different forms of hedging tools of e.g. an office with a residential property company. Table (2) contains the t-statistics of Welch's t-test for the sources of liquidity across property segments. The results of the t-test, whether the segment means are equal to the sample mean, indicate that 10 of 21 
conditional means are significantly different to the overall sample mean.

Table 2: Cross-Industry Variance for Financial Liquidity Instruments

\begin{tabular}{|c|c|c|c|c|c|c|c|c|c|}
\hline \multirow[b]{2}{*}{ Property Focus } & \multicolumn{3}{|c|}{ LEV } & \multicolumn{3}{|c|}{$\mathrm{CCE}$} & \multicolumn{3}{|c|}{ LOC } \\
\hline & $\mathrm{N}$ & Mean & t-stat & $\mathrm{N}$ & Mean & t-stat & $\mathrm{N}$ & Mean & t-stat \\
\hline All & 558 & 0.406 & & 558 & 0.015 & & 558 & 0.162 & \\
\hline Office & 103 & 0.411 & -0.5 & 103 & 0.012 & $2.261^{*}$ & 103 & 0.167 & -0.597 \\
\hline Residential & 103 & 0.424 & -1.779 & 103 & 0.011 & $3.337^{* *}$ & 103 & 0.167 & -0.737 \\
\hline Retail & 122 & 0.446 & $-3.445 * * *$ & 122 & 0.013 & 1.295 & 122 & 0.164 & -0.264 \\
\hline Industrial & 40 & 0.407 & -0.072 & 40 & 0.018 & -0.87 & 40 & 0.162 & -0.052 \\
\hline Hotel & 58 & 0.374 & 1.931 & 58 & 0.022 & $-2.492^{*}$ & 58 & 0.146 & 1.448 \\
\hline Diversified & 59 & 0.415 & -0.549 & 59 & 0.018 & -1.714 & 59 & 0.131 & $3.286 * *$ \\
\hline Others & 73 & 0.327 & $6.054 * * *$ & 73 & 0.019 & -1.584 & 73 & 0.182 & $-2.278^{*}$ \\
\hline
\end{tabular}

Note: This table shows the t-statistics (t-stat) of Welch's t-test. LEV refers to the market leverage. CCE refers to cash \& cash equivalents, LOC to lines of credit available, both scaled by year-beginning total assets. ${ }^{* *},{ }^{* *}$, and ${ }^{*}$ denote statistical significance at the $1 \%, 5 \%$, and $10 \%$ levels, respectively.

Therefore, we compare the results of the high and low subsamples. According to the firm characteristics of the respective twelve property segments, a firm enters the low (high) subsample, if it yields a value below (above) the $45^{\text {th }}\left(55^{\text {th }}\right)$ percentile for a given firm characteristic. The characteristics are LEV, CCE, LOC, MB, ROA and Size. Furthermore, subsamples are constructed for the boom years (1996-1999, 2003-2007 and 2009-2010), bust years (2000-2002 and 2008) and for the sample before the late-2000s financial crisis (before 2008). Moreover, the attributes of whether a firm 'is rated as investment grade', 'has an above-median cash flow volatility' or 'experienced positive as opposed to negative cash-flow changes' are identified accordingly.

\section{Model}

The concept underlying this paper is basically that of combining the cash flow statement approach of Gatchev, Pulvino, and Tarhan (2010) with the balance-sheet view of Chen and Zhao (2007).

More specifically, the ideas that we adopt are a system of equations, estimated by weighted least squares, where the weight is reciprocal to the number of observations per year. By also following the advice of Petersen (2009), the methodological difference, is 
that we decided to include year dummies in order to account for time effects..$^{9}$ An even more important difference is that we do not need to de-fine our identity, but eliminate 48 firm-year observations which do not satisfy the conditions in equations $(1)$ and $(2) \cdot 10$

$\begin{aligned} & \text { Cash Flow from Operations }{ }_{i, t} \\ + & \text { Cash Flow from Financing } i, t \\ + & \text { Cash Flow from Investment } t_{i, t} \\ = & \Delta \text { Cash and Cash Equivalents }(C C E)_{i, t}\end{aligned}$

Through equation (1), we relate the operating cash flow (CF_Op) to changes in balance sheet items by modeling

$$
\begin{aligned}
& \text { Operating } C F_{i, t} \stackrel{!}{=}-\left(\text { Financing } C F_{i, t}+\text { Investment } C F_{i, t}\right)-\ldots \\
& -\Delta \text { Depreciable Property } \text { P }_{i, t}+\Delta S T D_{i, t}+\Delta L T D_{i, t}+\ldots \\
& +\Delta \text { Common Equity }_{i, t}+\Delta \operatorname{Resid}(A l l)_{i, t}+\text { error }_{i, t}
\end{aligned}
$$

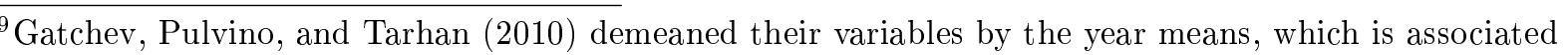
with a manual adjustment of confidence intervals (especially in smaller samples like ours). Accordingly, after demeaning our sample, the year dummies re-main jointly significant.

${ }_{10}^{10}$ Gatchev, Pulvino, and Tarhan (2010) did not capture the whole cash-flow statement and thus had to define this identity in combination with a penalty function. 
where:

$$
\begin{aligned}
& N F I_{i, t}=\text { Financing } C F_{i, t}+\text { Investment } C F_{i, t} \\
& \Delta \operatorname{Resid}(\text { All })_{i, t}=\Delta \operatorname{Resid}(\text { Assets })_{i, t}+\Delta \operatorname{Resid}(\text { Liab.\&Equi. })_{i, t} \\
& \Delta \operatorname{Resid}\left(\text { Assets }_{i, t}=\Delta \text { Total Asset } s_{i, t}-\Delta \text { Depreciable Property }_{i, t}-\ldots\right. \\
& -\Delta(C C E)_{i, t} \\
& \Delta \operatorname{Resid}\left(\text { Liab.\&Equi. }_{i, t}=\Delta\left(\text { Liabilities }_{i, t}-\text { Total Debt }_{i, t}\right)+\ldots\right. \\
& +\Delta \text { Total Mezzanine }{ }_{i, t}+\Delta \text { Preferred Equity } \text { E }_{i, t} \\
& \text { error }_{i, t}=-\Delta \text { Total Assets }_{i, t}+\Delta S T D_{i, t}+\Delta L T D_{i, t}+\ldots \\
& +\Delta \text { Common Equity }_{i, t}+\Delta \operatorname{Resid}(\text { Liab.\&Equi. })_{i, t}
\end{aligned}
$$

The first two summands of equation (2) expresses the change in total assets, while the second row expresses the change in equity plus liabilities of the variables in our focus. The change in Resid(All) subsumes the remaining aggregates of the balance sheet.11

Moreover, we allow for a maximum deviation of $\$ 100,000$ in equation (2)

$$
\mid \text { error }_{i, t} \mid \stackrel{!}{<} 100,000
$$

Therefore, the basic model accounting for Spotlight B can be written as

\footnotetext{
${ }^{11}$ The sum of financing and investment cash flow was originally allocated to the change in Resid(All), which should only play a minor role for the system dynamics. However, the dynamics of this variable were too often significant, due to the substantial relevance of these two cash flows.
} 


$$
\left(\begin{array}{c}
\Delta \operatorname{Resid}(A l l)_{i, t} \\
\Delta S T D_{i, t} \\
\Delta L T D_{i, t} \\
\Delta E Q U_{i, t} \\
\Delta D P R O P_{i, t} \\
\Delta N F I_{i, t}
\end{array}\right)=\Gamma \cdot\left(\begin{array}{c}
\Delta \operatorname{Resid}(A l l)_{i, t-1} \\
\Delta S T D_{i, t-1} \\
\Delta L T D_{i, t-1} \\
\Delta E Q U_{i, t-1} \\
\Delta D P R O P_{i, t-1} \\
\Delta N F I_{i, t-1}
\end{array}\right)+\Lambda \cdot C F_{-} O p_{i, t}+\ldots
$$

$$
+\Pi \cdot\left(\begin{array}{c}
S \& P 500_{i, t} \\
M B_{i, t} \\
R O A_{i, t} \\
S I Z E_{i, t}
\end{array}\right)+\Psi \cdot\left(\begin{array}{c}
\text { Rating }_{i, t} \\
O p_{-} \text {Risk }_{i, t} \\
\text { Inv_Shock }_{i, t} \\
\text { FFO_Shock } \\
i, t
\end{array}\right)+\epsilon_{i, t}
$$

or in compact form

$$
Y=\Gamma \cdot L . Y+\Lambda \cdot C F_{-} O p+\Pi \cdot C+\Psi \cdot D+\epsilon_{i, t}
$$

'Y' represents all the right hand side variables of equation (2), which are also implemented as lagged regressors..$^{12}$ Operating cash flows 'CF_Op', as well as the firm characteristics 'C', namely S\&P500, MB, ROA and Size are proposed as contemporaneous independent variables. The dummies 'D' (Rating, Op-Risk, Inv_Shock and FFO_Shock) complete equation (3).13 By construction, it follows that all coefficients per row add up to zero, but the operating CF's impact on 'Y' sum to one.

\footnotetext{
${ }^{12}$ Besides Gatchev, Pulvino, and Tarhan (2010), the funding cycle of Brown and Riddiough (2003) in conjunction with Riddiough and Wu (2009) would also suggest this dynamic framework.

${ }^{13}$ We also considered dummies like 'incorporated in Delaware or Maryland', 'firm is a REIT', 'firm age' etc., that are partially implemented in real estate corporate finance research. However, due to the limited useful and significant insights thus obtained, we disregard these characteristics.
} 
Table 3: Basic Model (according to equation (3p)

\begin{tabular}{|c|c|c|c|c|c|c|c|}
\hline & $\begin{array}{l}(1) \\
\text { Resid(All) }\end{array}$ & $\begin{array}{l}(2) \\
\text { STD }\end{array}$ & $\begin{array}{l}(3) \\
\text { LTD }\end{array}$ & $\begin{array}{l}(4) \\
\text { EQU }\end{array}$ & $\begin{array}{l}(5) \\
\text { DPROP }\end{array}$ & $\begin{array}{l}(6) \\
\text { NFI }\end{array}$ & $\begin{array}{l}(1)+(2)+(3)+. . \\
+(4)-(5)-(6) \\
\text { Balance Sheet } \\
\text { Identity }\end{array}$ \\
\hline L.Resid(All) & $\begin{array}{l}0.133 \\
(0.62)\end{array}$ & $\begin{array}{l}-0.299^{*} \\
(-1.84)\end{array}$ & $\begin{array}{l}-0.720^{*} \\
(-1.90)\end{array}$ & $\begin{array}{l}-0.527^{* *} \\
(-2.50)\end{array}$ & $\begin{array}{l}-0.965^{* *} \\
(-2.08)\end{array}$ & $\begin{array}{l}-0.447^{* * *} \\
(-5.53)\end{array}$ & 0.0000033 \\
\hline L.STD & $\begin{array}{l}0.168 \\
(0.82)\end{array}$ & $\begin{array}{l}-0.660^{* * *} \\
(-3.65)\end{array}$ & $\begin{array}{l}-0.231 \\
(-0.58)\end{array}$ & $\begin{array}{c}-0.409^{*} \\
(-1.96)\end{array}$ & $\begin{array}{l}-0.686 \\
(-1.42)\end{array}$ & $\begin{array}{l}-0.446^{* * *} \\
(-5.37)\end{array}$ & 0.0000077 \\
\hline L.LTD & $\begin{array}{l}0.181 \\
(0.90)\end{array}$ & $\begin{array}{l}-0.260 \\
(-1.54)\end{array}$ & $\begin{array}{l}-0.604 \\
(-1.60)\end{array}$ & $\begin{array}{l}-0.447 * * \\
(-2.26)\end{array}$ & $\begin{array}{c}-0.681 \\
(-1.48)\end{array}$ & $\begin{array}{l}-0.449^{* * *} \\
(-5.62)\end{array}$ & 0.0000061 \\
\hline L.EQU & $\begin{array}{l}0.179 \\
(0.91)\end{array}$ & $\begin{array}{c}-0.234 \\
(-1.39)\end{array}$ & $\begin{array}{c}-0.576 \\
(-1.57)\end{array}$ & $\begin{array}{l}-0.460 * * \\
(-2.40)\end{array}$ & $\begin{array}{c}-0.646 \\
(-1.50)\end{array}$ & $\begin{array}{l}-0.445^{* * *} \\
(-5.60)\end{array}$ & 0.0000014 \\
\hline L.DPROP & $\begin{array}{l}-0.166 \\
(-0.80)\end{array}$ & $\begin{array}{l}0.288^{*} \\
(1.68)\end{array}$ & $\begin{array}{l}0.784^{* *} \\
(2.01)\end{array}$ & $\begin{array}{l}0.558^{* * *} \\
(2.74)\end{array}$ & $\begin{array}{l}1.009 * * \\
(2.14)\end{array}$ & $\begin{array}{l}0.456^{* * *} \\
(5.52)\end{array}$ & -0.0000057 \\
\hline L.NFI & $\begin{array}{l}-0.217 \\
(-1.49)\end{array}$ & $\begin{array}{l}0.052 \\
(0.38)\end{array}$ & $\begin{array}{l}0.677^{* *} \\
(2.01)\end{array}$ & $\begin{array}{l}0.518^{* * *} \\
(3.26)\end{array}$ & $\begin{array}{l}0.906^{* *} \\
(2.42)\end{array}$ & $\begin{array}{l}0.124^{* *} \\
(2.05)\end{array}$ & -0.0000091 \\
\hline $\mathrm{CF}_{-} \mathrm{Op}$ & $\begin{array}{l}0.169 \\
(1.03)\end{array}$ & $\begin{array}{l}-0.006 \\
(-0.05)\end{array}$ & $\begin{array}{l}1.192^{* * *} \\
(3.48)\end{array}$ & $\begin{array}{l}0.453^{* *} \\
(2.48)\end{array}$ & $\begin{array}{l}1.760^{* * *} \\
(4.08)\end{array}$ & $\begin{array}{l}-0.952^{* * *} \\
(-15.62)\end{array}$ & 0.9999973 \\
\hline S\&P500 & $\begin{array}{l}0.021 \\
(1.30)\end{array}$ & $\begin{array}{l}-0.005 \\
(-0.26)\end{array}$ & $\begin{array}{l}0.068^{*} \\
(1.75)\end{array}$ & $\begin{array}{l}0.055^{* * *} \\
(3.22)\end{array}$ & $\begin{array}{l}0.123^{* * *} \\
(4.32)\end{array}$ & $\begin{array}{l}0.016^{* *} \\
(1.98)\end{array}$ & -0.0000002 \\
\hline MB & $\begin{array}{l}-0.005^{* *} \\
(-2.11)\end{array}$ & $\begin{array}{l}-0.002 \\
(-0.72)\end{array}$ & $\begin{array}{l}0.019^{* * *} \\
(3.61)\end{array}$ & $\begin{array}{l}-0.008^{* * *} \\
(-2.69)\end{array}$ & $\begin{array}{l}0.004 \\
(0.52)\end{array}$ & $\begin{array}{l}0.001 \\
(0.84)\end{array}$ & 0.0000001 \\
\hline ROA & $\begin{array}{l}-0.003^{*} \\
(-1.98)\end{array}$ & $\begin{array}{l}-0.000 \\
(-0.54)\end{array}$ & $\begin{array}{l}-0.007 * * * \\
(-3.86)\end{array}$ & $\begin{array}{l}0.006^{* * *} \\
(4.36)\end{array}$ & $\begin{array}{l}-0.005^{* *} \\
(-2.17)\end{array}$ & $\begin{array}{l}0.001^{* *} \\
(1.99)\end{array}$ & 0.0000000 \\
\hline Size & $\begin{array}{l}-0.001 \\
(-0.58)\end{array}$ & $\begin{array}{c}-0.001 \\
(-0.87)\end{array}$ & $\begin{array}{c}-0.003 \\
(-0.86)\end{array}$ & $\begin{array}{c}-0.002 \\
(-0.73)\end{array}$ & $\begin{array}{l}-0.008 \\
(-1.53)\end{array}$ & $\begin{array}{l}0.000 \\
(0.89)\end{array}$ & 0.0000000 \\
\hline Rating & $\begin{array}{c}-0.003 \\
(-0.50)\end{array}$ & $\begin{array}{l}-0.005 \\
(-1.32)\end{array}$ & $\begin{array}{l}0.014 \\
(1.60)\end{array}$ & $\begin{array}{l}0.002 \\
(0.43)\end{array}$ & $\begin{array}{l}0.009 \\
(0.92)\end{array}$ & $\begin{array}{c}-0.001 \\
(-0.83)\end{array}$ & 0.0000000 \\
\hline Op_Risk & $\begin{array}{l}-0.003 \\
(-0.61)\end{array}$ & $\begin{array}{l}0.001 \\
(0.37)\end{array}$ & $\begin{array}{l}-0.001 \\
(-0.12)\end{array}$ & $\begin{array}{l}-0.001 \\
(-0.27)\end{array}$ & $\begin{array}{c}-0.003 \\
(-0.33)\end{array}$ & $\begin{array}{l}-0.000 \\
(-0.51)\end{array}$ & 0.0000000 \\
\hline Inv_Shock & $\begin{array}{l}0.011^{* * *} \\
(2.68)\end{array}$ & $\begin{array}{c}-0.004 \\
(-1.19)\end{array}$ & $\begin{array}{c}-0.012 \\
(-1.65)\end{array}$ & $\begin{array}{l}-0.016^{* * *} \\
(-4.21)\end{array}$ & $\begin{array}{l}-0.021^{* *} \\
(-2.38)\end{array}$ & $\begin{array}{c}-0.001 \\
(-0.65)\end{array}$ & 0.0000002 \\
\hline FFO_Shock & $\begin{array}{c}-0.001 \\
(-0.13)\end{array}$ & $\begin{array}{l}0.003 \\
(0.65)\end{array}$ & $\begin{array}{l}-0.005 \\
(-0.65)\end{array}$ & $\begin{array}{l}-0.013^{* *} \\
(-2.57)\end{array}$ & $\begin{array}{c}-0.016^{*} \\
(-1.69)\end{array}$ & $\begin{array}{c}-0.000 \\
(-0.00)\end{array}$ & -0.0000001 \\
\hline $\mathrm{N}$ & 558 & 558 & 558 & 558 & 558 & 558 & \\
\hline adj. R-sq & 0.024 & 0.160 & 0.229 & 0.209 & 0.225 & 0.676 & \\
\hline $\mathrm{N}$ _clust & 140 & 140 & 140 & 140 & 140 & 140 & \\
\hline $\operatorname{Mean}(y)$ & 0.021 & 0.008 & 0.049 & 0.030 & 0.105 & -0.062 & \\
\hline $\operatorname{St} . \operatorname{Dev}(\mathrm{y})$ & 0.048 & 0.048 & 0.094 & 0.052 & 0.108 & 0.026 & \\
\hline
\end{tabular}

Note: This table shows results based on equation (3). STD refers to short-term debt, LTD to long-term debt, EQU to common equity, DPROP to depreciable property, NFI to the net of the financing and investment cash flow, Resid(All) subsumes all remaining balance sheet items as defined in equation (2), all measured in first differences and scaled by year-beginning total assets. CF Op refers to operating cash flow scaled by year-beginning total assets. S\&P500 refers to the continuous return of the S\&P500 index, MB to the ratio of market value over book value of equity, ROA to return on assets, Size to the ln of total assets. The dummy Rating is equal to one, if a firm has an investment grade rating, Op Risk is equal to one, if a firm's cash flows are above the median in the respective property segment, Inv Shock is equal to one, if a firm's percentage change in $\mathrm{MB}$ is above the $55^{\mathrm{th}}$ percentile in the respective property segment, FFO Shock is equal to one, if a firm's percentage change of FFO is below the $45^{\text {th }}$ percentile in the respective property segment, and zero otherwise. Year dummies are not reported. N denotes firm-year observations of each equation, $\mathrm{N}_{-}$cluster denotes the number of observed firms, Mean(y) and St.Dev.(y) represent mean and standard deviation of the dependent variable. The last column illustrates the accounting identity defined in equation 2. T-stats are in parenthesis, ***, **, and * denote statistical significance at the $1 \%, 5 \%$, and $10 \%$ levels, respectively.

This is basically the modeling aspect of emphasizing leverage. Liquidity management is essential in modeling financing decisions. Therefore, the other spotlight highlights the debt ratio from interactions with competing sources of financial flexibility, namely CCE and LOC. Therefore, the full model adds LEV, CCE and LOC to equation (3). The quadratic terms of these three sources are also implemented, since no previous study has 
so far explored potential non-linear relationships between LEV, CCE and LOC. In the manner, interactions between the three instruments of financial flexibility are dependent on the original level, which is the main reason for the quadratic terms (i.e. Sufi 2007, for LOC and CCE or Gamba and Triantis (2008), for cash and debt).

$$
Y=\Gamma \cdot L . Y+\Lambda \cdot C F_{-} O p+\Pi \cdot C+\Psi \cdot D+\Sigma \cdot S+\Omega \cdot S^{2}+\epsilon_{i, t}
$$

where

$$
S=\left(\begin{array}{l}
L E V_{i, t-1} \\
C C E_{i, t-1} \\
L O C_{i, t-1}
\end{array}\right)
$$

Finally, we challenge equation (4) with respect to three different 'sets' of conditions. The first simply splits our sample in economic up- and downturns, as well as the subsample before the recent late 2000s financial crisis. Second, rather than interpreting firm characteristics typically used in capital structure research (MB, ROA and Size), we compare subsamples with low and high levels for these variables of interest. The same is done for the sources of financial flexibility, in order to take a further look at how relationships are dependent on the original level (rankings are defined according to the respective property focus, see data section). In addition, subsamples are compared with respect to Rating, Op_Risk and the change in $\mathrm{CF}_{-} \mathrm{Op}$.

$$
Y(X \mid \text { subsample })=\Gamma \cdot L . Y+\Lambda \cdot C F_{-} O p+\Pi \cdot C+\Psi \cdot D+\Sigma \cdot S+\Omega \cdot S^{2}+\epsilon_{i, t}
$$




\section{Results}

This section is also separated in Spotlight A and Spotlight B and all conditional subsamples are considered. However, only full sample and conditional estimations with respect to time and MB, ROA and Size, as well as LEV, CCE and LOC are reported 144

\section{$5.1 \quad$ Spotlight A}

In the literature section, it was pointed out that the negative LOC-CCE interactions seem to be empirically robust. Across the 22 subsamples, we find a robust negative (non-linear) relationship for CCE on LOC, but only six subsamples reveal reverse causality.

The literature section did not provide a robust prediction of how LEV fits into the dynamics of this discussion. Initially, LEV yields contrary interactions with LOC. If significant, the 'negative' causality runs from LEV to LOC and only for the squared terms (14/22 subsamples). Furthermore, we find four negative (four positive) impacts of LOC on LEV, most obviously for the subsamples low (high) CCE and low (high) LOC firms. This could simply be due to the chronology of the "funding cycle" of Riddiough and Wu (2009). If LEV increases due to the use of LOC, then a negative relationship follows technically. Alternatively, if debt decreases due to the repayment of outstanding debt, the next funding cycle is established by blowing up LOC. On the other hand, if LOC increases, it is not clear when the firm draws these lines. Moreover, the LOC-LEV interactions are exclusively the case for the squared terms (except for small firms).

Second, LEV-CCE interactions are much weaker. LEV positively drives CCE in 6/22 subsamples, which is also restricted to the squared terms. In contrast, CCE negatively impacts on LEV in $3 / 22$ sub-samples. This is the case for the high LOC and high CCE firms, as well as for firms with high CF volatility. A reason for this might be that on the one hand, having a reasonable amount of one of these two sources, the marginal value of lowering debt as the third source increases. On the other hand, high CCE or

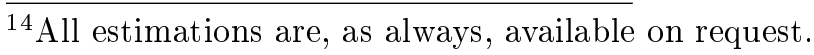


LOC subsamples imply that these firms are able to afford a drop in financial flexibility by lowering $\mathrm{CCE}$, accompanied by an increase in debt. In the case of firms with highly volatile cash flows, we argue that CCE will be used before debt increases, in the event of a CF shortfall. Accordingly, both instruments will be 'reloaded' (more CCE, less debt) after positive movements from the $\mathrm{CF}$ mean.

In short, in four of the six subsamples, in which LEV is significant with respect to CCE, LEV is also significant for LOC. Alternatively, the relationship of LEV on CCE (LOC) is always positive (negative). If significant, CCE on LEV is always negative and in these subsamples, LOC on LEV is always positively significant. Hence, the above stochastic argument of a reverse relationship of CCE and LOC on LEV and vice versa holds for each of the 22 subsamples. This can be observed directly in the sub-samples high CCE, high LOC and high Op_Risk.

Before discussing the remaining variables, four findings are highlighted. First, the expected strong, empirical, negative relationship of LOC and CCE is reduced to a causality from CCE to LOC. Second, causality also seems to be stronger for LEV on LOC and for LEV on CCE, compared to the reverse causalities. Third, the financial flexibility perspective provides the basis for a complementary relationship of CCE and LEV and a substitutive one of CCE and LOC. Finally, the dependence on the original level of one or the other source is strongly suggested by a dominance of significant squared terms. Also, the change in signs of significant relationships in the case of LOC on LEV, dependent on low/high CCE or LOC firms, clearly demonstrate the importance of the original level.

It was expected that CF would positively affect LOC (Sufi $(2009))$, whereas a CF-CCE relationship was expected for constraint subsamples. However, $\mathrm{CF}$ plays only a minor role within this framework. The results suggest only one positive estimate for LEV (during economic downturns), one negative estimate for CCE (low MB firms) and two positive estimates for LOC (high Size and low Op_Risk firms). S\&P500 affects LEV negatively, 
while it affects CCE positively; LOC is negatively affected by the S\&P500 continuous returns for high ROA, low LEV and high LOC firms. Differences in the market and book value of equity (MB) are negatively associated with LEV. However, MB influences LOC positively (10/22 subsamples), fully consistent with financial flexibility, where firms with growth opportunities prepare to counter underinvestment due to potential liquidity gaps. As expected, CCE plays a subordinate role as a hedging tool, but is, as with LOC, positively driven by MB in five subsamples. In accordance with the argument given for LEV-CCE interactions, two of the five subsamples are low LEV and high LOC firms, hence, the marginal value of accumulating $\mathrm{CCE}$ as the third source increases in response to a MB increase.

Accordingly, ROA and Size affect LEV negatively. However, the latter relationship is much weaker. Moreover, both CCE and LOC are influenced marginally by (positive) ROA dynamics. In contrast, a negative Size effect applies to both liquidity instruments, implying that firm size substitutes for financial flexibility to some extent. This is even more the case for LOC (16/22 subsamples). Accordingly, high LEV, low CCE and low LOC firms yield a negative size effect for LOC, while their counterparts do not reveal such effects with any significance. Low LEV firms even yield a positive relationship of Size on CCE $\sqrt{15}$ This exception is illustrated by the subsample Size itself, in which large firms yield a negative relationship of Size to LOC, whereas small firms yield a positively significant relationship.

The impact of the set of dummies is less evident. Rated firms in general have lower levels of CCE, moreover they have less debt. Firms with higher Op_Risk seem to have higher levels of borrowing and lending in order to smooth out the variance. ${ }^{16}$ Shocks pri-

\footnotetext{
${ }^{15}$ Since growth opportunities approximate for a need for financial flexibility, we observe a positive estimate of Size on CCE for high MB firms, whereas the counterpart yields a negative one.

${ }^{16}$ Despite little significant estimates, the size subsample again delivered ambiguous results. Small firms with an operating risk hold less LOC, but their counterparts just do the reverse. This is contrary to the negative Size effect for liquidity instrument stated above. A reason for this might be that small firms with volatile cash flows receive less LOC in general, while big firms additionally hedge against CF shortfalls contrary to big firms without a high operating risk.
} 
marily affect LEV, investment shocks negatively (19/22 subsamples), FFO shocks positively (8/22 subsamples) ${ }^{17}$ There is some additional discussion with respect to the shock dummies in the section on the mechanical aspects of leverage.

\subsection{Spotlight $\mathrm{B}$}

The interpretation of Spotlight $\mathrm{B}$ is reduced to the discussion of LTD, EQU, DPROP and LEV 18

First of all, the motivating aspects described above are addressed by investigating how often there is an impact on LTD or EQU, but LEV is unaffected and vice versa. For this reason, we employ two approaches. On the one hand, we follow the suggestion of Gatchev, Pulvino, and Tarhan (2010) by interpreting the number of significant estimators in rows of matrix $\Gamma$ of equation (5) as impulses of the independent variable, and significances in columns as responses (recall table (4)). Focusing on responses, we find 18 (27) significant off-diagonal estimators for LTD (EQU), but only 22 for LEV.19 We additionally pose the simple question of how often LTD and/or EQU are affected by capital structure variables, but LEV remains unchanged. Across the 22 subsample regressions, it is primarily MB that affects LTD and/or EQU 19 times, while LEV remains unchanged.

With respect to Size, we rarely find significant effects, since we scaled by the yearbeginning total as-sets. As stated above, a negative relationship of Size is evidently the case for LEV. MB positively (negatively) impacts LTD (EQU) and hence yields a signifi-

\footnotetext{
${ }^{17}$ One exception is that Inv_Shock shows a positive sign to LEV before the late-2000s financial crisis.

${ }^{18}$ However, worth mentioning is the fact that the sum of financing and investment CF shows the most considerable significances in our system. Hence, findings of Gatchev, Pulvino, and Tarhan (2010) that these two 'activities' would balance each other so that financing-investment sensitivities are mitigated cannot be stated for the real estate market. Moreover, aspects of debt maturity as suggested by Giambona, Harding, and Sirmans (2008) or Barclay, Marx, and Smith (2003) are simply modeled, though not reported, by distinguishing between short and long term debt.

${ }^{19}$ Assuming persistence in accounting variables, we ignore significances of lagged dependent variables. When we include lagged dependent variable, it is leverage, of course, which shows the highest persistence, since it is not measured in first differences (LTD 19, EQU 29, and LEV 42). Dependent variables with more responses are also said to be "shock absorbers" (Gatchev, Pulvino, and Tarhan (2010)).
} 
cantly negative sign to LEV, moreover, rarely it affects DPROP positively. In accordance with the arguments relating to the mechanical aspects, a negative MB-LEV relationship may be attributed to market valuation, which is in the numerator of $\mathrm{MB}$, but in the denominator of LEV. Analogously, this is assumed to be valid for EQU.

Finally, ROA positively (negatively) drives EQU (LTD and LEV) - which was expected. However, a negative impact of 'profitability' on DPROP can again be attributed either to mechanics (median depreciable property accounts for $96 \%$ of total assets, which is the denominator of ROA) or is a further illustration of cash flows being a superior measure of a company's soundness.

CF strictly shows positive impacts on LTD, EQU and DPROP and does not affect LEV, apart from the 'bust-subsample'. The most impressive instance is the very high magnitude of estimates of $\mathrm{CF}$ for these three variables. While a $\$ 1$ increase in operating cash flow robustly leads EQU to increase within a range of $\$ 0.35$ to $\$ 0.66$, estimators of LTD are between $\$ 0.27$ (low Size) and a much higher $\$ 1.37$ (low Op_Risk). DPROP is affected between $\$ 1.01$ (low LEV) to $\$ 2.80$ (during Bust) by a $\$ 1.00$ increase of CF. These results suggest that firms use the improvement in cash-flow-based credit-quality ratios due to cash-flow increases and acquire more debt. Taking the full sample estimation as a benchmark, for each subsample, it can be stated that the higher the CF-LTD sensitivity the higher the CF-DPROP sensitivity.

In order to understand this, recall the identity of equation (3). Assume also that Resid(All) and STD play a minor role, and further assume that a $\$ 1$ change in operating $\mathrm{CF}$ transfers to a $\$ 1$ change in the sum of financing and investment $\mathrm{CF}$ whereas EQU is very robustly affected by about $\$ 0.52$ (whole sample). A strong connection between LTD and DPROP caused by operating CF then follows logical-ly.

Accordingly, S\&P500 also positively influences all variables considered, but positive 
Figure 2: "Liaison" of Debt and Investment via Cash Flows

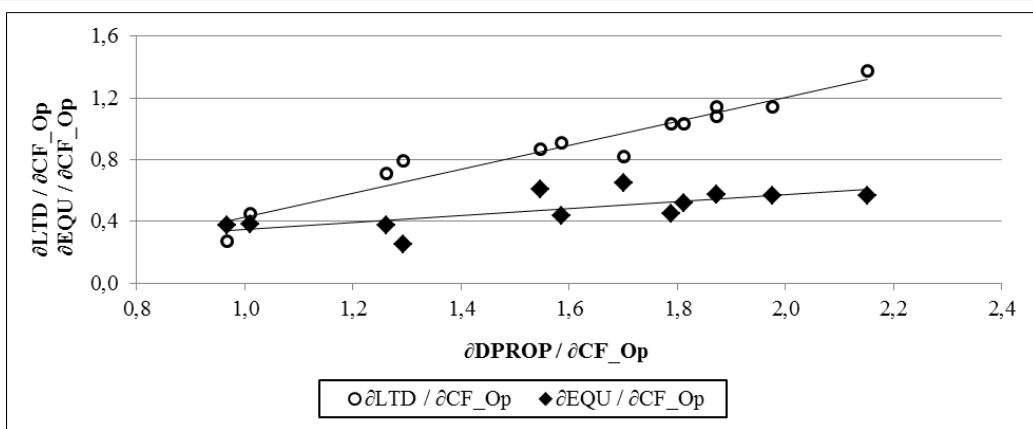

Note: This figure plots the marginal impacts of operating cash flows ( $\mathrm{CF}$ Op) to changes in long-term debt (LTD) and changes in common equity (EQU) against the marginal impacts of $\mathrm{CF}_{-}$Op to changes in depreciable property (DPROP).

market returns imply a lower LEV. The dummies Rating and Op_Risk rarely yield significant estimates. Across all estimations, INV_Shock and FFO_Shock yield a negative sign for LTD, EQU and DPROP very robustly. However, while INV_Shock results in a lower LEV, a FFO_Shock is compensated for by a higher LEV. This confirms the debt capacity argument of future investment opportunities, by investment shocks robustly resulting in a lower leverage. Therefore, if both variables are significant in the same equation, the magnitudes of the estimates are fairly equal. This also highlights the need to identify drivers of financial decisions, since an investment shock seems to affect balance sheet changes similarly to an FFO shock, but the inference for LEV yields reverse dynamics.

\subsection{Book Leverage}

While MB yields a negative relationship to market LEV, it turns into a positively significant one for book LEV. Since it was argued that the negative correlation results from a mechanical relationship, one would rely on book LEV. However, consider two identically characterized firms with different market valuations. The higher valued firm would certainly have better access to financing sources. Yet, would a firm that is not otherwise constrained be interested in this? The calculus of financial flexibility would refute such behavior. Indeed, we find no significant results for most of the 'good' subsamples (high LOC, high ROA, high Size, rated firms and low Op_Risk). Most surprisingly, the Inv_Shock dummy does not change its sign, even though it is less often significant (9 for 
book versus 19 for market LEV). In line with the original motivation for this approximation, it is significantly negative, especially for financially inflexible firms. On the one hand, one might see this as a further indication of the interactions of the three sources suggested in this paper being valid. On the other hand, it is evident that especially firms that are financially constrained and/or are confronted with potential underinvestment preserve debt capacity.

A further important difference is that book leverage is very sensitive to CF. Specifically, a $\$ 1.00$ increase in CF translates into about the same increase in debt. ROA remains robustly negative and Size remains understated 20 FFO_Shock is only significant twice, suggesting that the bulk of variance in substantial FFO declines is priced by the capital market. Moreover, general causalities stated for market LEV do not change, despite a lesser appearance of linear and squared terms being significant.

With respect to Spotlight B, the approach of Gatchev, Pulvino, and Tarhan (2010), we find the opposite. That is, we obtain 12 (23) off-diagonal elements for LTD (EQU) of $\Gamma$ in equation (3) but 54 for LEV. There is even more evidence of LEV eliminating information, since we count 5/2/3 significant estimates of MB/ROA/Size for LTD and/or EQU, whereas LEV remains unchanged across the 22 subsamples.

\section{Conclusion}

This paper emphasizes the importance of financial flexibility as the critical missing link for an empirically viable capital structure study. Financial flexibility allows firms to access and restructure their financing activities at a low cost. Furthermore, it prevents firms from financial distress during economic downturns and allows for investments in valueraising projects when they arise. We decided to investigate the capital structure of US Real Estate Investment Trusts (REITs) and Real Estate Operating Companies (REOCs) by two approaches, spotlights A and B. In our investigation, financial flexibility is defined

\footnotetext{
${ }^{20}$ In this sense, results based on book leverage suggest the pecking-order theory to be valid.
} 
in the sense of anticipating liquidity management instruments of leverage (LEV), cash \& cash equivalents (CCE) and lines of credit (LOC). At the beginning of this paper, the position of leverage as one of the sources of financial flexibility (Spotlight A), as well as technical attributes of this ratio (Spotlight B) were outlined.

This study can be seen as a bridge between emphasizing the characteristics of leverage in the function of a ratio on the one hand, and classifying leverage as a driver of liquidity management on the other hand. One of our findings is that leverage (LEV) drives cash \& cash equivalents (CCE) positively, but drives lines of credit (LOC) negatively. While the latter result, as well as the substitutive relationship of cash \& cash equivalents and lines of credit are backed by the existing literature, the positive LEV-CCE relationship is contrary to previous studies. This underlines the importance of credit lines for firms' liquidity management. The positive influence of leverage on cash \& cash equivalents can be explained by firms' strategy to accumulate cash in order to fund investments when profitable opportunities arise. In addition, our interaction results of LEV, CCE and LOC are consistent with the typical funding cycle suggested by Riddiough and Wu (2009). The typical funding cycle can be separated into the following steps. Anticipating investment opportunities, a firm arranges lines of credit with its bank. Subsequently, it begins to work with its acquisition and after it reaches stable inflows, equity or long-term debt securities are issued. Hence, the earnings are used to pay down lines of credit and recreate a new funding cycle. This development can be found in our results. The investment shock dummy - unique to our research an measuring if a firm faces strong investment opportunities - yields significant negative results with respect to the observation of firms lowering leverage, i.e. preserving debt capacity after investment shocks. In contrast, FFO shocks - measuring if a firm exhibits little change in funds from operations (FFO) affect balance sheet aggregates very similarly to investment shocks, but generally result in leverage increases. This highlights the need to identify drivers of financial decisions, since an investment shock seems to affect balance sheet changes similarly to an FFO shock, but the inference for leverage yields reverse dynamics.

Furthermore, our results derive the following major implications for managers. So far, 
real estate companies have almost abandoned cash as a hedging instrument. High cash reserves would hedge against the risk of underinvestment and cash flow shortfalls, but mainly against the latter. However, our results show that this hedging capacity is rarely used. In addition, decision makers tend to overdo investments after a cash flow increase. This can be noticed during economic downturns, before the late-2000s financial crisis, for highly leveraged firms, for low cash \& cash equivalents firms and for relatively large firms. 


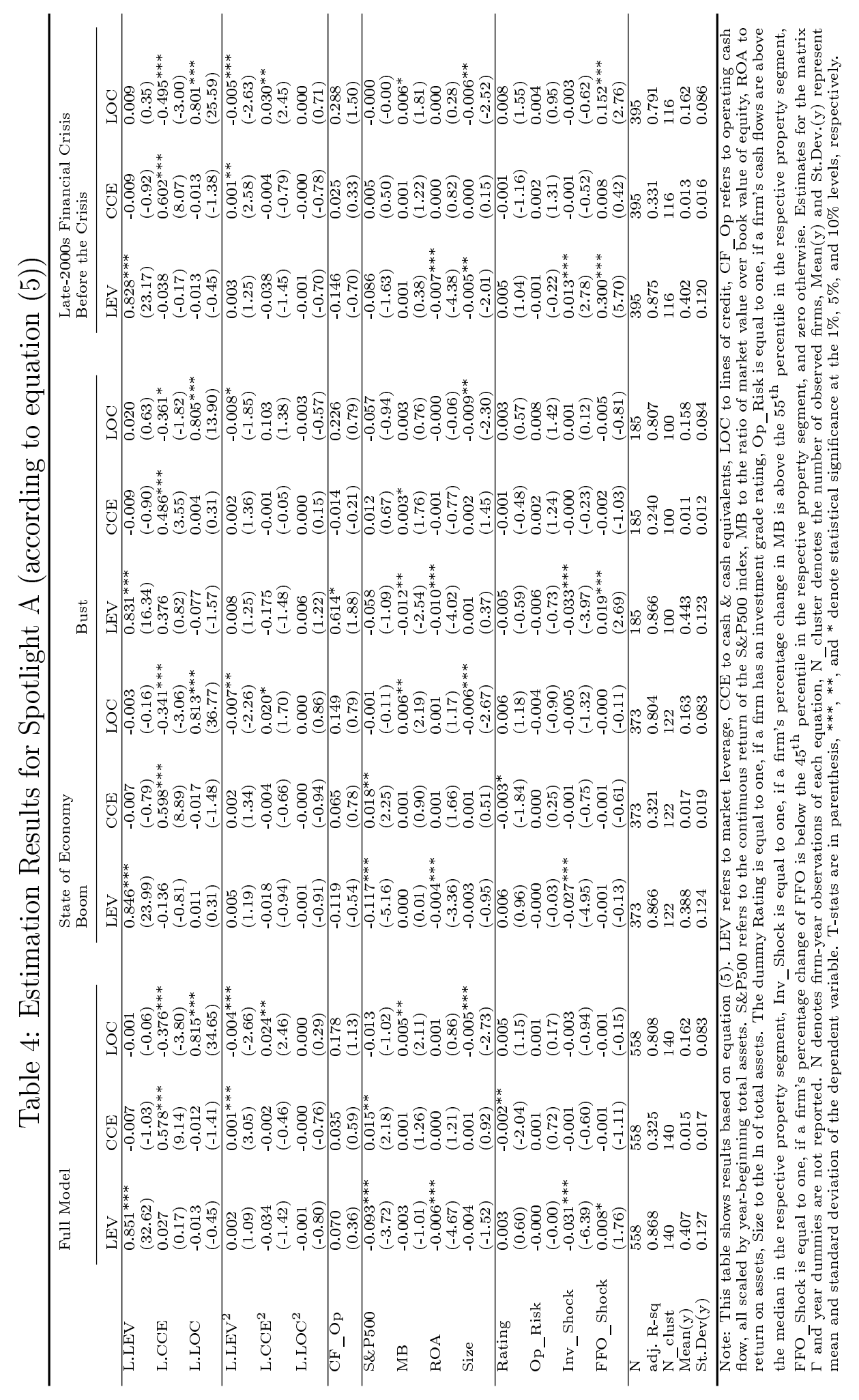




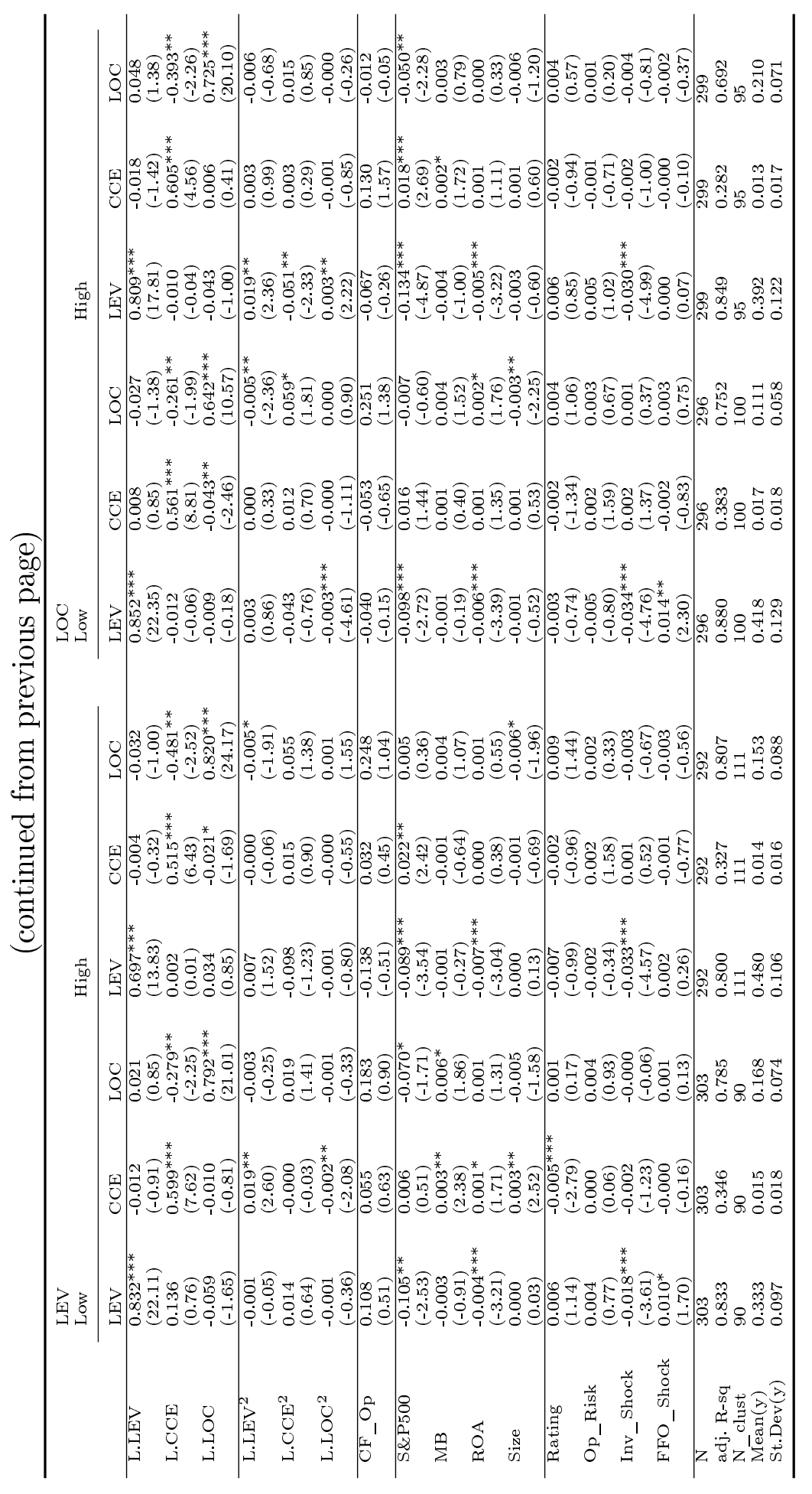




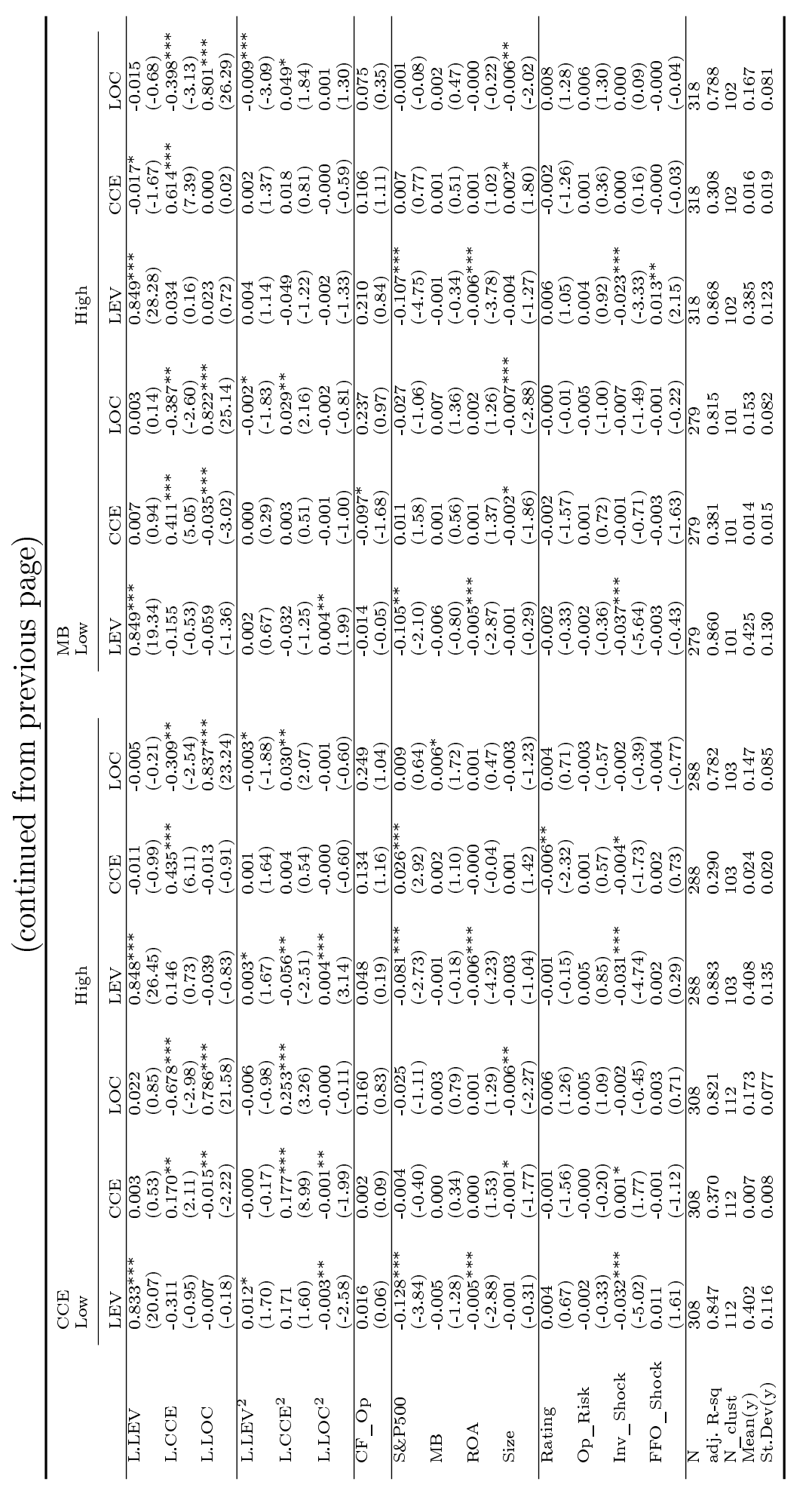




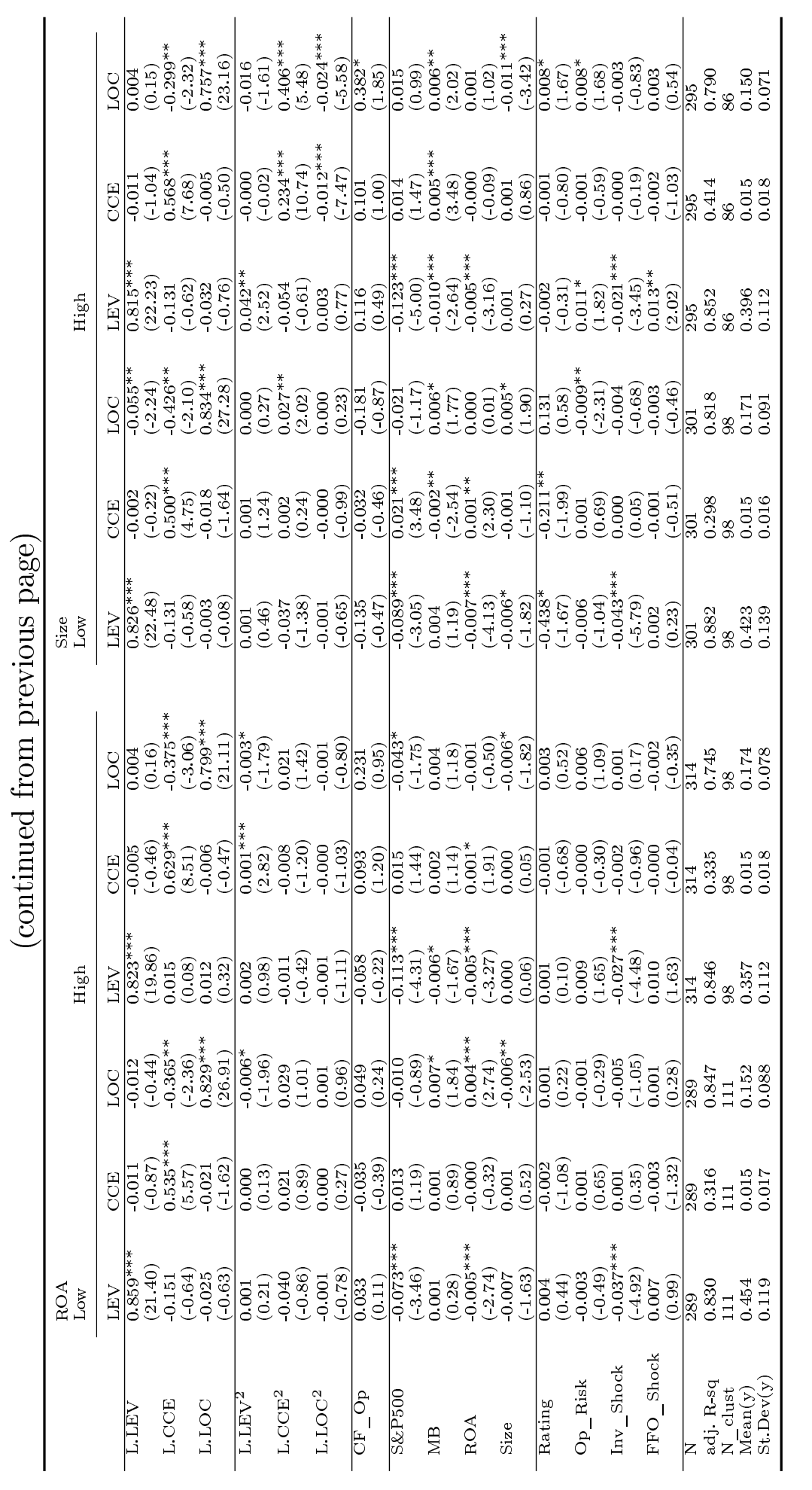




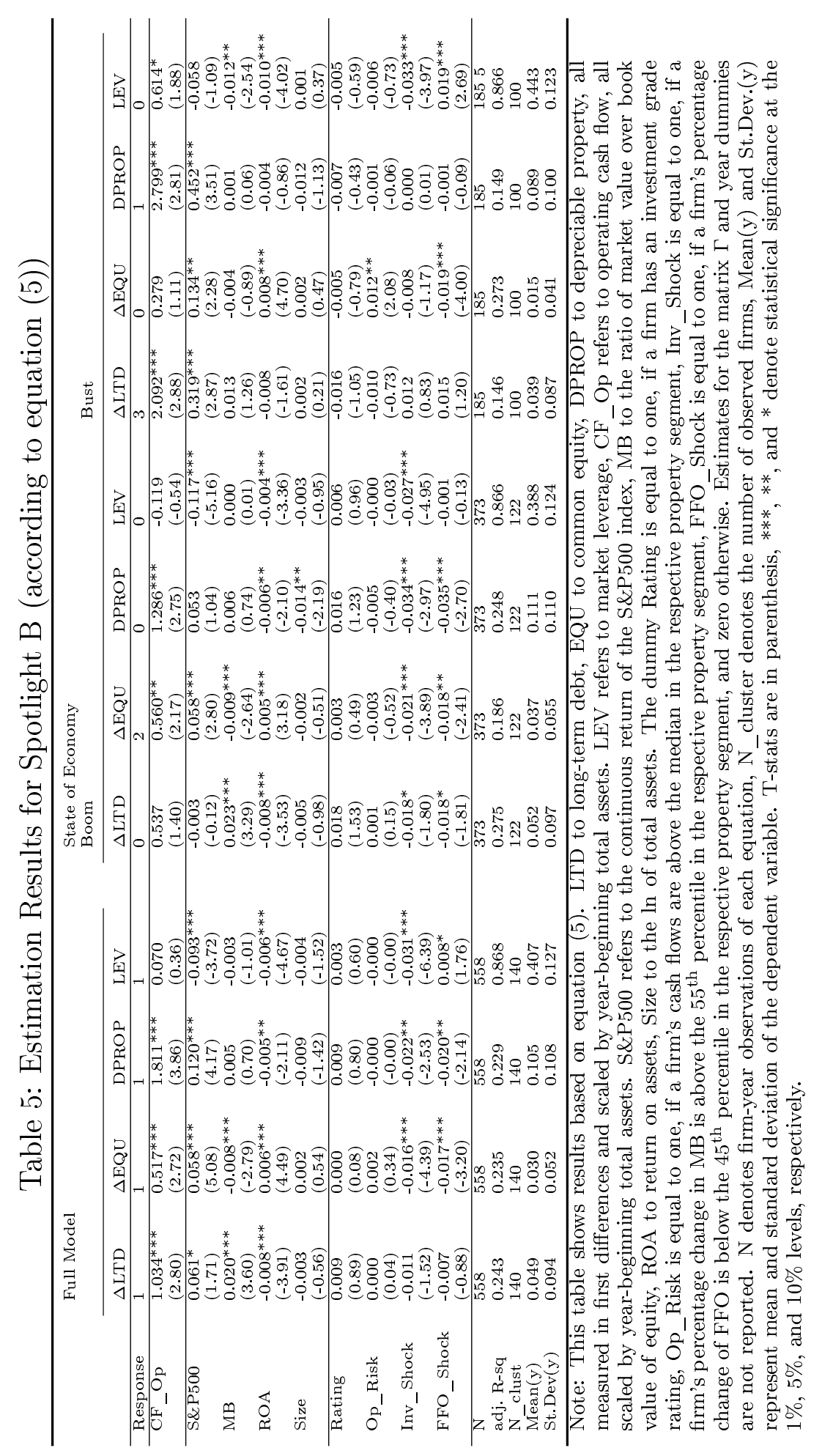




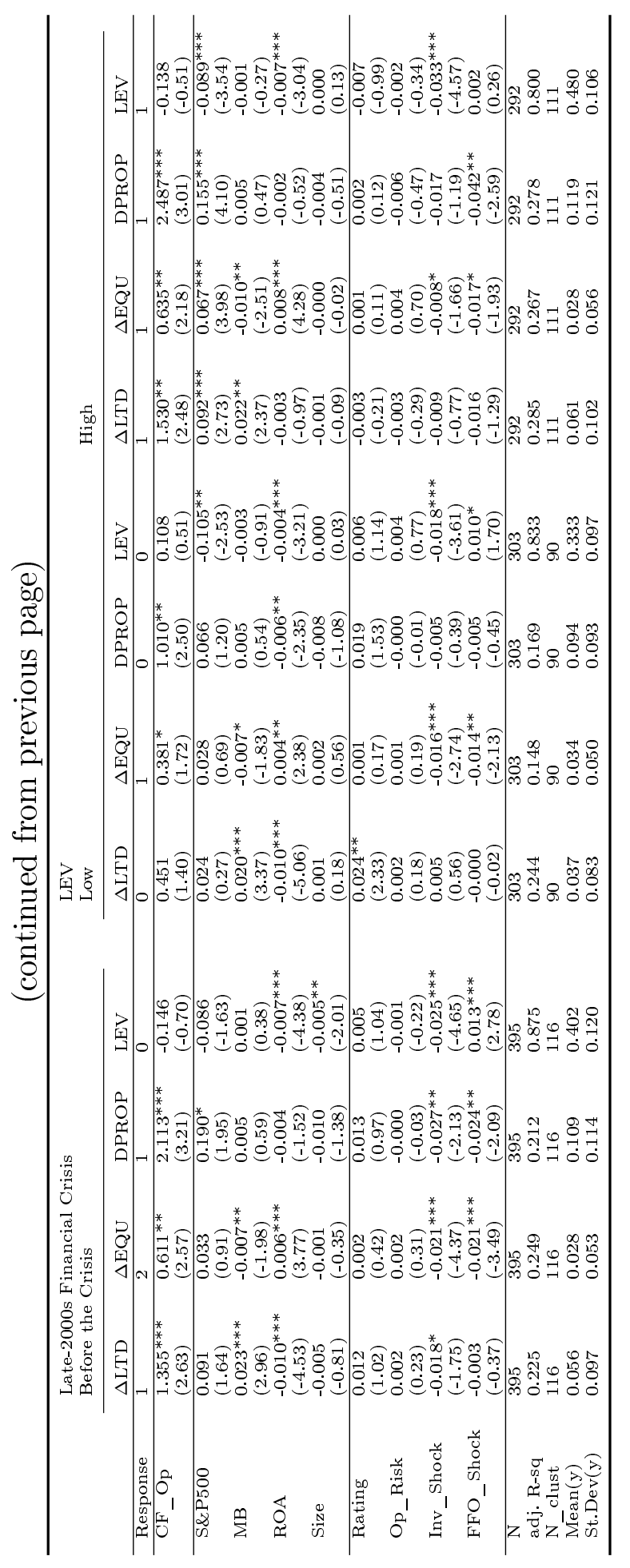




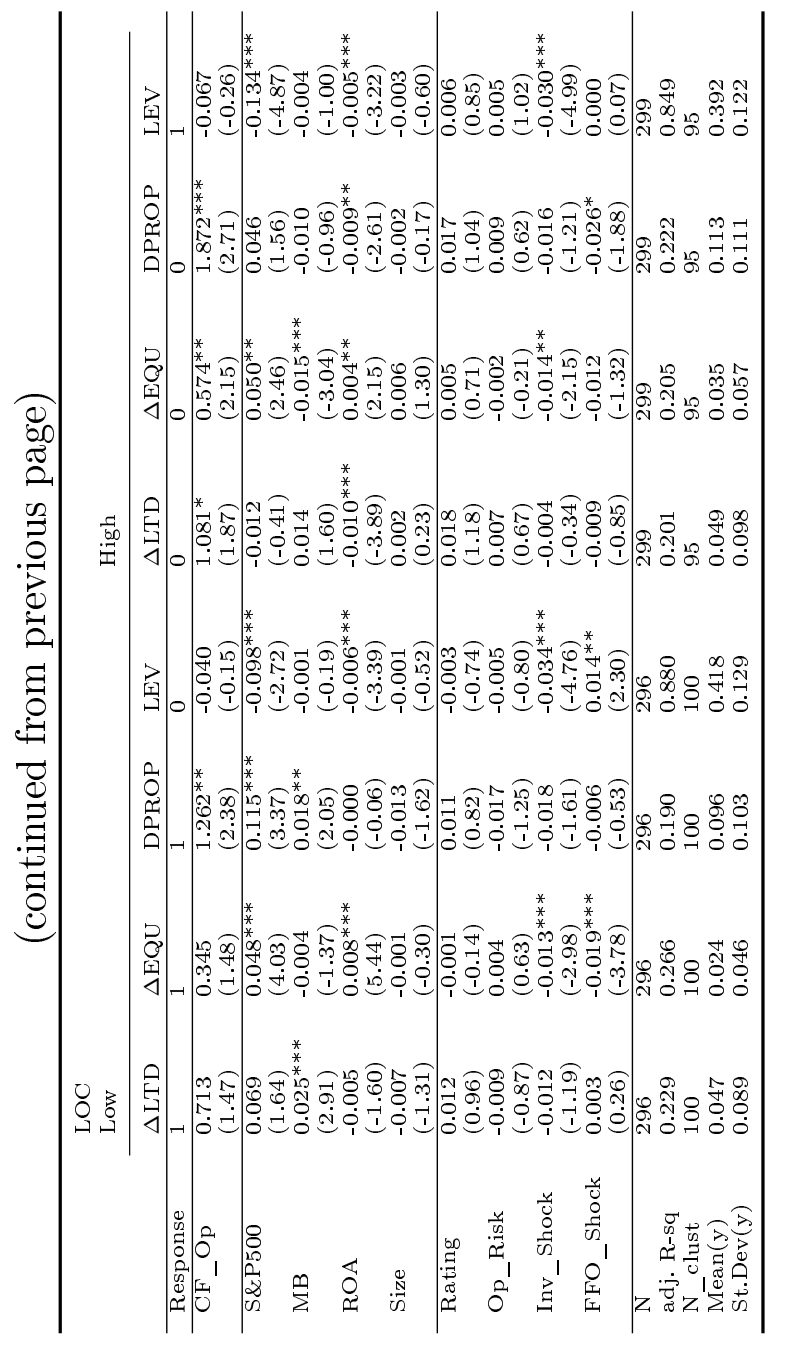




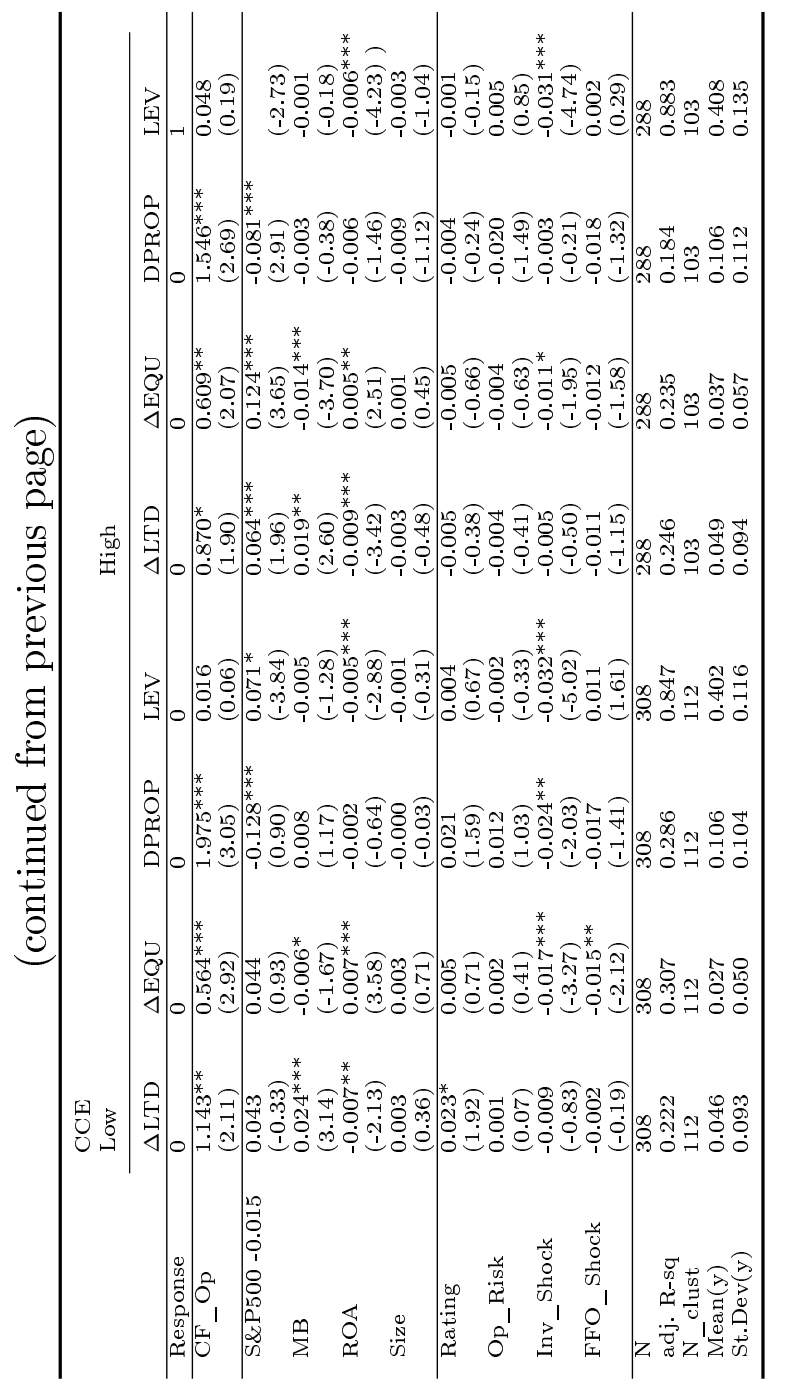




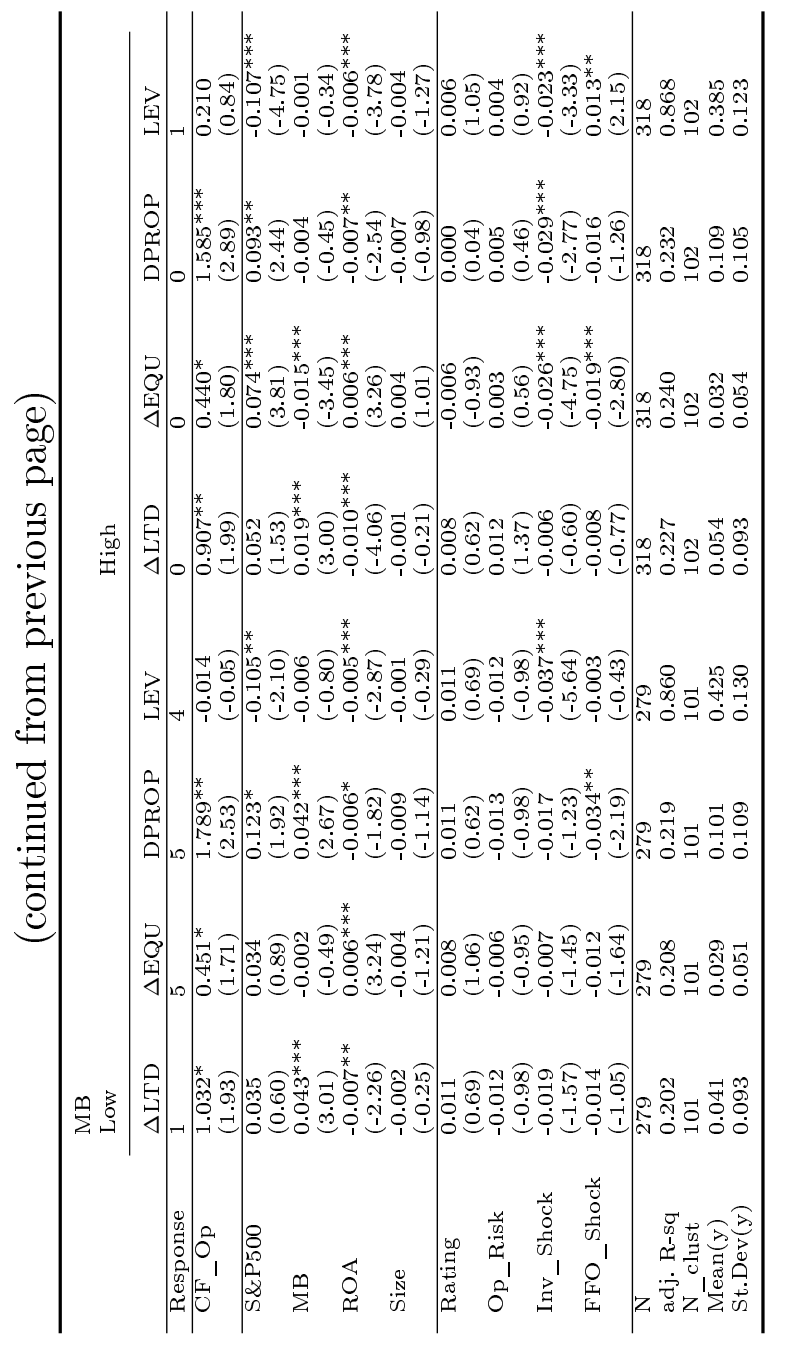




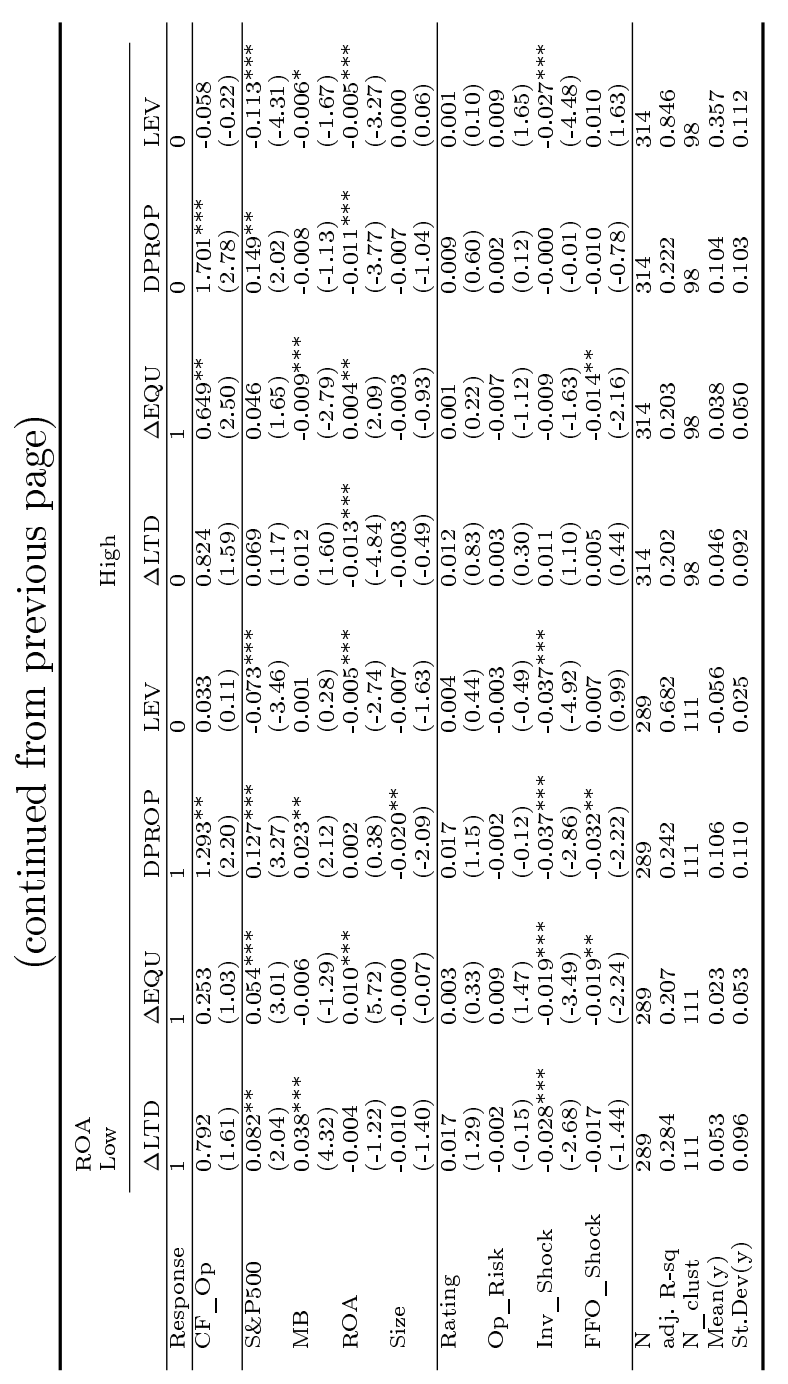




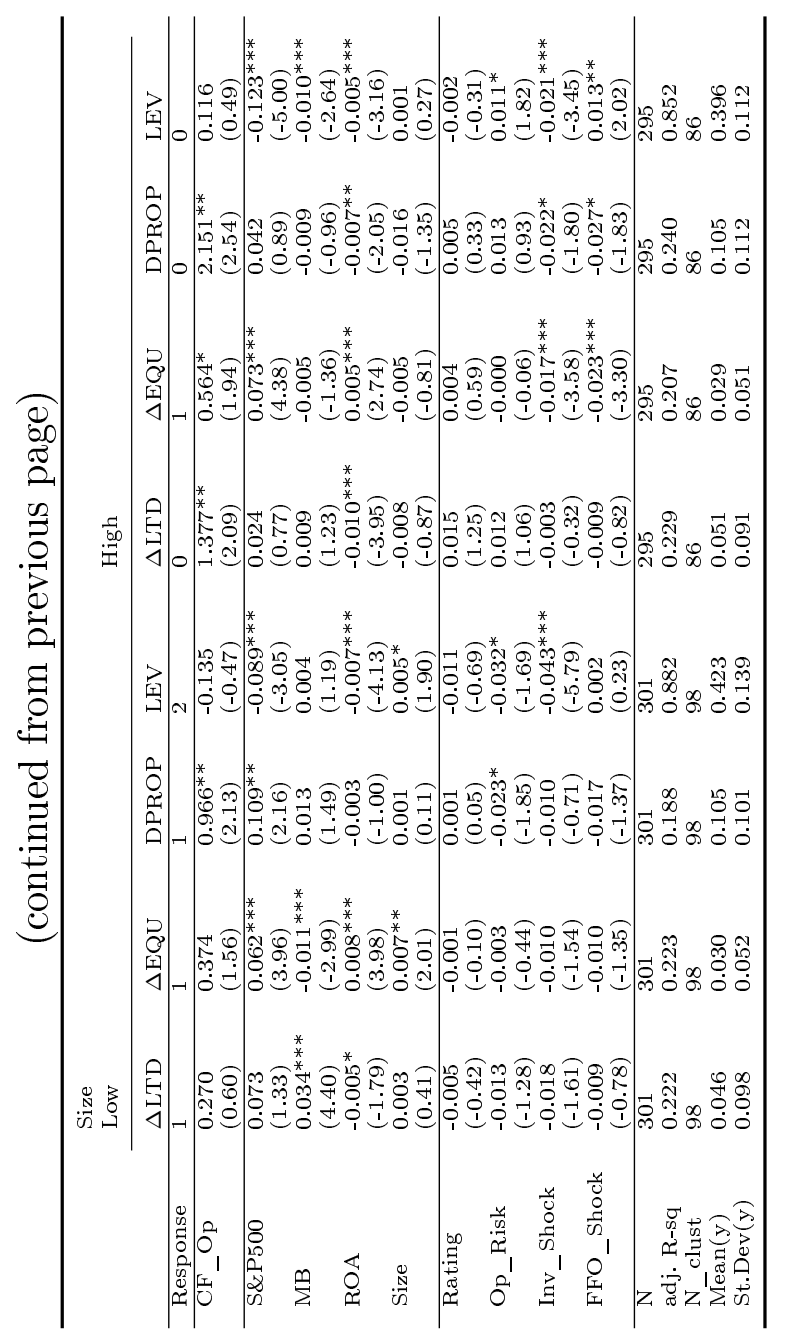




\section{References}

Acharya, V.V., H. Almeida, and M. Campello, 2007, Is cash negative debt? a hedging perspective on corporate financial policies, Journal of Financial Intermediation 16, $515-554$.

Almeida, H., and M. Campello, 2007, Financial constraints, asset tangibility, and corporate investment, Review of Financial Studies 20, 1429-1460.

An, H., W.G. Hardin, and Z. Wu, 2010, Information asymmetry and corporate liquidity management: Evidence from real estate investment trusts, Journal of Real Estate Finance and Economics, forthcoming.

Barclay, M.J., L.M. Marx, and Jr.C.W. Smith, 2003, The joint determination of leverage and maturity, Journal of Corporate Finance 9, 149-167.

Blouin, J., J.E. Core, and W. Guay, 2010, Have the tax benefits of dept been overestimated?, Journal of Financial Economics 98, 195-213.

Brown, D.T., and T.J. Riddiough, 2003, Financing choice and liability structure of real estate investment trusts, Real Estate Economics 31, 313-346.

Campello, M., J.R. Graham, and C.R. Harvey, 2010, The real effects of financial constraints: Evidence from a financial crisis, Journal of Financial Economics 97, 470-487.

Chen, L., and X. Zhao, 2007, Mechanical mean reversion of leverage ratios, Economics Letters 95, 223-229.

DeAngelo, H., and L. DeAngelo, 2007, Capital structure, payout policy, and financial flexibility, Working paper, Marshall School of Business.

Denis, D.J., and V. Sibilkov, 2010, Financial constraints, investment, and the value of cash holdings, Review of Financial Studies 23, 247-269.

Ertugrul, M., and E. Giambona, 2011, Property segment and REIT capital structure, Journal of Real Estate Finance and Economics, forthcoming. 
Feng, Z., C. Ghosh, and C.F. Sirmans, 2007, On the capital structure of real estate investment trusts (REITs), Journal of Real Estate Finance and Economics 34, 81-105.

Flannery, M.J., and K.P. Rangan, 2006, Partial adjustment toward target capital structures, Journal of Financial Economics 79, 469-506.

Gamba, A., and A. Triantis, 2008, The value of financial flexibility, Journal of Finance $63,2263-2296$.

Gatchev, V.A., T. Pulvino, and V. Tarhan, 2010, The interdependent and intertemporal nature of financial decisions: An application to cash flow sensitivities, Journal of Finance 65, 725-763.

Giambona, E., J.P. Harding, and C. Sirmans, 2008, Explaining the variation in REIT capital structure: The role of asset liquidation value, Real Estate Economics 36, 111137.

Graham, J.R., and C.R. Harvey, 2001, The theory and practice of corporate finance: evidence from the field, Journal of Financial Economics 60, 187-243.

Hardin, W.G., M.J. Highfield, M.D. Hill, and G.W. Kelly, 2009, The determinants of REIT cash holdings, Journal of Real Estate Finance and Economics 39, 39-57.

Hardin, W.G., and Z. Wu, 2010, Banking relationships and REIT capital structure, Real Estate Economics 38, 257-284.

Harrison, D.M., C.A. Panasian, and M.J. Seiler, 2011, Further evidence on the capital structure of REITs, Real Estate Economics, forthcoming.

Hill, M.D., G.W. Kelly, and W.G. Hardin, 2010, Market value of REIT liquidity, Journal of Real Estate Finance and Economics, forthcoming.

Hovakimian, A., G. Hovakimian, and H. Tehranian, 2004, Determinants of target capital structure: The case of dual debt and equity issues, Journal of Financial Economics $71,517-540$. 
Leary, M.T., and M.R. Roberts, 2010, The pecking order, debt capacity, and information asymmetry, Journal of Financial Economic 95, 332-355.

Lins, K.V., H. Servaes, and P. Tufano, 2010, What drives corporate liquidity? an international survey of cash holdings and lines of credit, Journal of Financial Economics 98, 160-176.

Modigliani, F., and M.H. Miller, 1958, The cost of capital, corporation finance and the theory of investment, American Economic Review 48, 261-297.

Opler, T., L. Pinkowitz, R. Stulz, and R. Williamson, 1999, The determinants and implications of corporate cash holdings, Journal of Financial Economics 52, 3-46.

Ozkan, A., and N. Ozkan, 2004, Corporate cash holdings: An empirical investigation of UK companies, Journal of Banking \& Finance 28, 2103-2134.

Petersen, M.A., 2009, Estimating standard errors in finance panel data sets: Comparing approaches, Review of Financial Studies 22, 435-480.

Riddiough, T.J., and Z. Wu, 2009, Financial constraints, liquidity management and investment, Real Estate Economics 37, 447-481.

Sufi, A., 2009, Bank lines of credit in corporate finance: An empirical analysis, Review of Financial Studies 22, 1057-1088. 